\title{
Beyond ferryl-mediated hydroxylation: 40 years of the rebound mechanism and $\mathrm{C}-\mathrm{H}$ activation
}

\author{
Xiongyi Huang ${ }^{1} \cdot$ John T. Groves ${ }^{1}$
}

Received: 31 August 2016 / Accepted: 3 November 2016 / Published online: 1 December 2016

(C) The Author(s) 2016. This article is published with open access at Springerlink.com

\begin{abstract}
Since our initial report in 1976, the oxygen rebound mechanism has become the consensus mechanistic feature for an expanding variety of enzymatic $\mathrm{C}-\mathrm{H}$ functionalization reactions and small molecule biomimetic catalysts. For both the biotransformations and models, an initial hydrogen atom abstraction from the substrate $(\mathrm{R}-\mathbf{H})$ by high-valent iron-oxo species $\left(\mathrm{Fe}^{\mathrm{n}}=\mathrm{O}\right)$ generates a substrate radical and a reduced iron hydroxide, $\left[\mathrm{Fe}^{\mathrm{n}-1}-\mathrm{OH} \cdot \mathrm{R}\right]$. This caged radical pair then evolves on a complicated energy landscape through a number of reaction pathways, such as oxygen rebound to form $\mathrm{R}-\mathrm{OH}$, rebound to a non-oxygen atom affording $\mathrm{R}-\mathrm{X}$, electron transfer of the incipient radical to yield a carbocation, $\mathrm{R}^{+}$, desaturation to form olefins, and radical cage escape. These various flavors of the rebound process, often in competition with each other, give rise to the wide range of $\mathrm{C}-\mathrm{H}$ functionalization reactions performed by iron-containing oxygenases. In this review, we first recount the history of radical rebound mechanisms, their general features, and key intermediates involved. We will discuss in detail the factors that affect the behavior of the initial caged radical pair and the lifetimes of the incipient substrate radicals. Several representative examples of enzymatic $\mathrm{C}-\mathrm{H}$ transformations are selected to illustrate how the behaviors of the radical pair $\left[\mathrm{Fe}^{\mathrm{n}-1}-\mathrm{OH} \cdot \mathrm{R}\right]$ determine the eventual reaction outcome. Finally, we discuss the powerful potential of "radical rebound" processes as a general paradigm for developing novel $\mathrm{C}-\mathrm{H}$ functionalization reactions with synthetic, biomimetic catalysts. We envision that new chemistry will continue to arise by bridging enzymatic "radical rebound" with synthetic organic chemistry.
\end{abstract}

John T. Groves

jtgroves@princeton.edu

1 Princeton University, Princeton, USA
Keywords Iron · Oxygenase $\cdot \mathrm{C}-\mathrm{H}$ activation $\cdot$ Rebound Radical $\cdot$ Metal oxo

$\begin{array}{ll}\text { Abbreviations } \\ \text { cpd I } & \text { Compound I } \\ \text { cpd II } & \text { Compound II } \\ \text { TMP } & \text { Tetramesitylporphyrin } \\ \text { TPFPP } & \text { Tetrakis(pentafluorophenyl)porphyrin } \\ \text { TDCPP } & \text { Tetrakis(2,6-dichlorophenyl)porphyrin } \\ \text { 4-TMPyP } & \text { Tetrakis(4- } N \text {-methylpyridyl)porphyrin } \\ \alpha \text { KG } & \alpha \text {-Ketoglutarate }\end{array}$

\section{Introduction}

Molecular oxygen, with its high oxidation potential, harbors considerable energy that powers aerobic life on earth. The driving force for biological oxygenation derives ultimately from the large, $80 \mathrm{kcal} / \mathrm{mol}$ favorable enthalpic change inherent to the four-electron reduction of oxygen to water. Paradoxically, however, $\mathrm{O}_{2}$ in its triplet ground state is a kinetically slow oxidant due to its thermodynamic stability. The one-electron reduction of ${ }^{3} \mathrm{O}_{2}$ to the superoxide ion is endergonic by $7.8 \mathrm{kcal} / \mathrm{mol}$ and the bond dissociation energy of $\mathrm{H}-\mathrm{OO}$. is only $47 \mathrm{kcal} / \mathrm{mol}$ [1-4]. Further, the triplet ground state of $\mathrm{O}_{2}$ imposes spin-flip barriers to two-electron processes involving closed shell reaction partners such as typical organic compounds $[5,6]$. To exploit the oxidative power of $\mathrm{O}_{2}$, nature has developed a diverse range of enzyme cofactors to activate triplet $\mathrm{O}_{2}$. A good example is the family of flavin-dependent oxidases and oxygenases, in which a reduced flavin reacts readily with triplet $\mathrm{O}_{2}$ to form hydroperoxyflavin intermediate despite the required triplet-to-singlet spin inversion [7-9]. The majority of $\mathrm{O}_{2}$-activation enzymes utilize cofactors 
containing transition metals, such as iron, copper, and occasionally manganese. These d-block metals, with their multiple spin states and oxidation states, are employed for numerous oxidative transformations in biology such as aliphatic $\mathrm{C}-\mathrm{H}$ hydroxylations and halogenations $[1,2,10-$ 16]. Perhaps not surprisingly, these metal-catalyzed oxidative enzymatic transformations share common mechanistic features in which oxygen is sequentially reduced to superoxo, peroxo, hydroxo, and high-valent metal-oxo intermediates, which are then exploited to activate substrates via hydrogen atom abstraction. The resulting substrate radical can then be transformed in a variety of ways (Fig. 1). Mechanistic examinations of these enzymatic transformations over the past four decades have revealed not only how these enzymes work. They have provided the impetus for the development of the field of bioinorganic chemistry, particularly high-valent metal coordination chemistry, and opened new frontiers in synthetic chemistry, led by novel, biomimetic catalytic systems for direct aliphatic $\mathrm{C}-\mathrm{H}$ functionalizations [17-21].

\section{Mechanisms of $\mathrm{C}-\mathrm{H}$ activation by cytochrome P450s and other iron-containing oxygenases}

The heme-thiolate-containing monooxygenases, cytochrome $\mathrm{P} 450$, have assumed a uniquely important position in the hierarchy of the field and served as prototypical example to our understanding of the iron-containing oxygenases [22-25]. P450 enzymes (now termed CYP) catalyze highly selective $\mathrm{C}-\mathrm{H}$ hydroxylations, as well as epoxidations, desaturations, dealkylations, and $\mathrm{C}-\mathrm{C}$ bond cleavage reactions in an extremely wide range of compounds. Typical substrates include xenobiotics such as pharmaceuticals and agrochemicals and precursors for the biosynthesis of steroids, terpenoids, alkaloids, antibiotics, pigments, antioxidants, etc. Bacterial P450s have been genetically engineered for large-scale bio-transformations [26, 27].

The consensus mechanism of P450-catalyzed hydroxylation that has come to be known as the oxygen rebound mechanism is shown in Fig. 2, as proposed by us in 1970s [28-30]. The key feature of this mechanism is the involvement of an oxoiron(IV) porphyrin cation radical intermediate (compound I) that abstracts a hydrogen atom from the substrate to form $\left[\mathrm{Fe}^{\mathrm{IV}}-\mathrm{OH} \cdot \mathrm{R}\right]$ and the subsequent rebound of the incipient substrate radical to a hydroxoiron(IV) intermediate (compound II) [31, 32].

The basic concept of the oxygen rebound mechanism stemmed from our early studies of Fenton's reagent-a mixture of hydrogen peroxide and ferrous salts that can hydroxylate alkanes [33, 34]. There were extensive debates in the field at that time regarding whether the hydrogenabstracting intermediate was a free hydroxyl radical or a

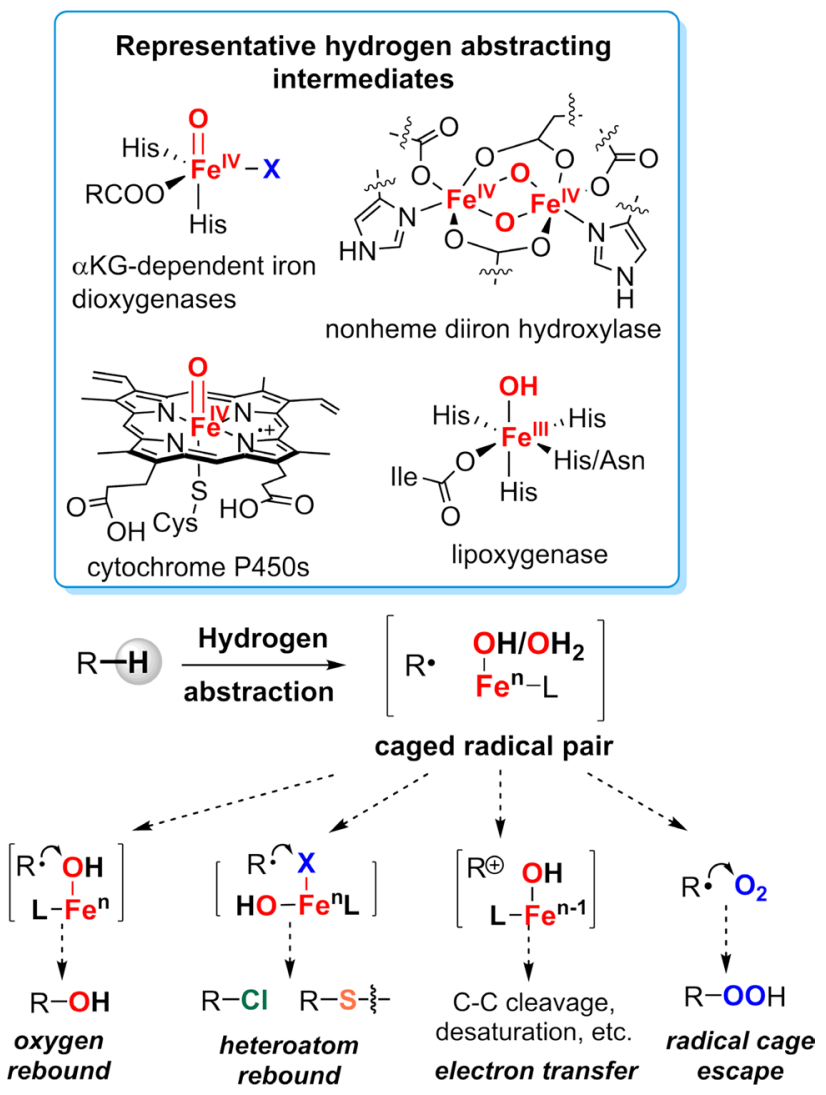

Fig. 1 A variety of biotransformations catalyzed by iron-containing oxygenases and their mechanistic features
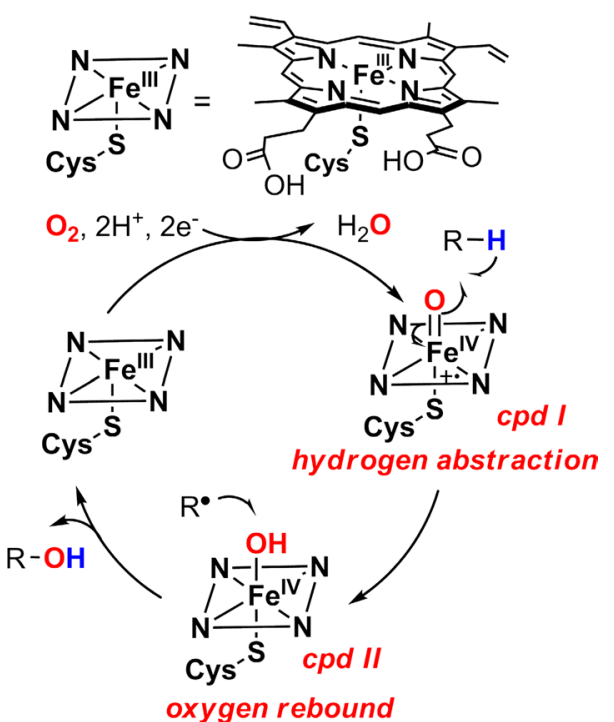

Fig. 2 Mechanism of aliphatic C-H hydroxylation catalyzed by cytochrome $\mathrm{P} 450$ (the oxygen rebound mechanism)

high-valent iron-oxo complex [35-38]. We became interested in this topic due to intriguing common features it shared with P450s. In 1976, we reported our finding that 
(a)

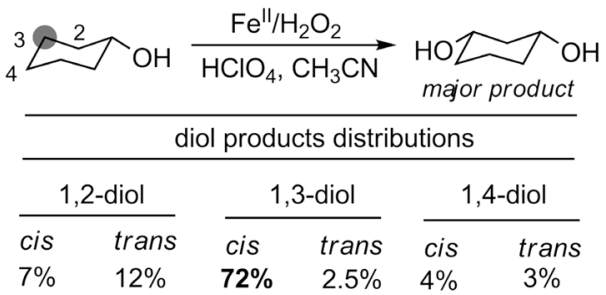

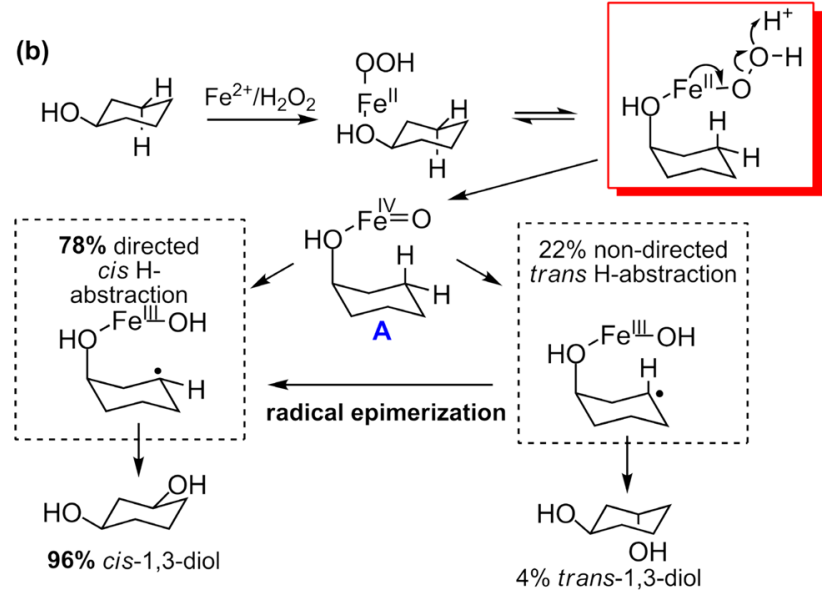

Fig. 3 a Hydroxylation of cyclohexanol by Fenton's reagent. b Directive effect in cyclohexanol hydroxylation by Fenton's reagent suggests a coordinated $\mathrm{Fe}^{\mathrm{IV}}=\mathrm{O}$ intermediate

a modified Fenton's reagent system $\left(\mathrm{Fe}^{2+}-\mathrm{H}_{2} \mathrm{O}_{2}-\mathrm{CH}_{3} \mathrm{CN}\right)$ catalyzed the hydroxylation of cyclohexanol affording cis-1,3-cyclohexanediol as the major diol product $(72 \%$, Fig. 3a) [28]. The high regioselectivity and the apparent directive effect of the $\mathrm{C}-1$ hydroxyl clearly pointed to an iron-mediated hydrogen abstraction, not hydroxyl radical. Furthermore, oxidation of trans-3-trans-5-dideuterocyclohexanol showed $78 \%$ cis-hydrogen abstraction at C-3 and $96 \%$ formation of $\mathrm{cis}$-1,3-diol. This apparent two-stage directive effect indicated a stepwise hydrogen abstraction/ radical oxidation sequence involving a coordinated ferryl intermediate, $\mathrm{Fe}^{\mathrm{IV}}=\mathrm{O}$ (A in Fig. 3b). The excess cis-1,3diol could be explained by a trans-C-3 hydrogen abstraction that then underwent radical oxidation on the syn side of the C-1 hydroxyl group (Fig. 3b). Today we know for sure that the two-electron oxygenation of ferrous ion by ozone produces such a ferryl species [39-43].

Closely following our studies of Fenton's reagent, we initiated a collaboration with colleague Jud Coon to investigate the mechanism of $\mathrm{C}-\mathrm{H}$ hydroxylation by rabbit liver microsomal cytochrome $\mathrm{P} 450$. The idea was to use selectively deuterated norbornane as a mechanistically diagnostic substrate for the enzyme. The results showed that phenobarbital-induced $\mathrm{P} 450_{\mathrm{LM} 2}$ (now CYP2B4) catalyzed the oxidation of exo,exo,exo,exo-2,3,5,6-tetradeuteronorbornane (1) at the $\mathrm{C}-2$ position with a significant amount of epimerization at the oxygenated carbon (Fig. 4a) [29].

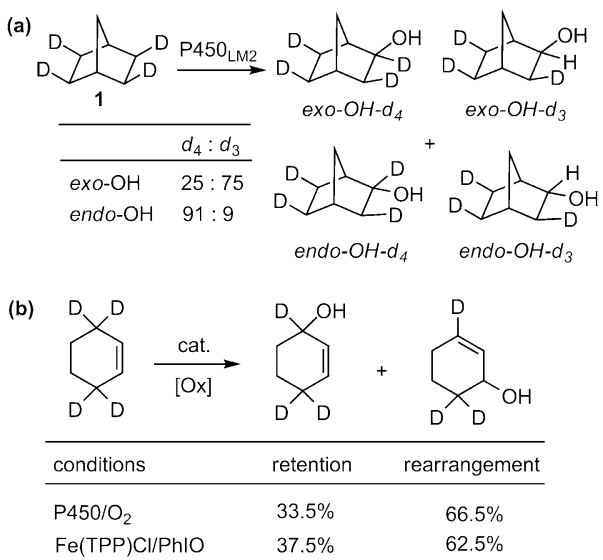

Fig. 4 a Oxidation of tetradeuteronorbornane catalyzed by $\mathrm{P} 450_{\mathrm{LM} 2}$. b Oxidation of 3,3,6,6-tetradeuterocyclohexene catalyzed by P450s and synthetic iron porphyrins

We further showed that the hydroxylation of selectively deuterated cyclohexene proceeded with substantial allylic scrambling (Fig. 4b) [44]. Significantly, synthetic iron porphyrin model compounds displayed the same behavior for both norbornane and cyclohexene substrates. These discoveries provided strong evidence for a step-wise, nonconcerted mechanism for $\mathrm{C}-\mathrm{H}$ scission and subsequent formation of the new $\mathrm{C}-\mathrm{OH}$ bond mediated by cytochrome $\mathrm{P} 450$ enzymes. The presence of the intermediate substrate radical, with a lifetime long enough to epimerize and rearrange has turned out to be an important and intrinsic property of the oxygen transfer event from oxoiron complexes. A prediction of the rebound process is that the newly formed alcohol product should still be coordinated to the heme iron. Subsequently, EPR-ENDOR evidence for just such an arrangement was provided by Hoffman et al. [45].

The characterization of key intermediates and analysis of their reactivity have afforded important insights into the nature of enzymatic processes. Much attention has been focused on the characterization of the hydrogen-abstracting intermediate compound I, which has been very challenging due to its highly reactive nature. The compound I of other heme-containing proteins such as horseradish peroxidase (HRP), catalase, and chloroperoxidase (CPO) are much more stable and have been well characterized as oxoiron(IV) porphyrin cation radicals [46-51]. However, these intermediates are not reactive towards unactivated hydrocarbons. Even the compound I of CPO, a hemethiolate protein like P450s, can only slowly hydroxylate weak benzylic $\mathrm{C}-\mathrm{H}$ bonds [52]. The first synthetic iron porphyrin compound I (species I in Fig. 5a) was characterized in 1981. Samples of I were bright green in color and displayed the characteristic broad absorbances at 406 and $645 \mathrm{~nm}$ in the visible spectrum of a porphyrin cation radical. The magnetic susceptibility of $\mathbf{I}, \mu_{\mathrm{B}}=4.2$, indicated 


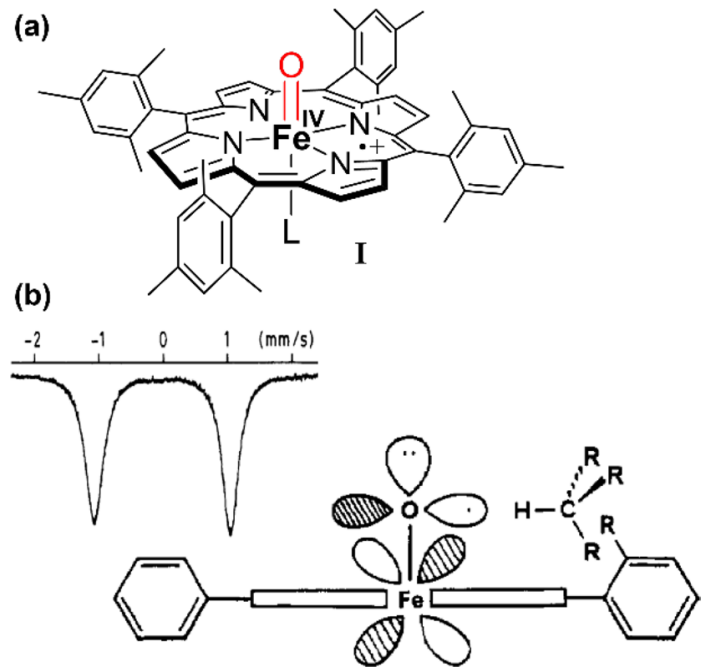

Fig. $5\left(\mathrm{TMP}^{+\cdot}\right) \mathrm{Fe}^{\mathrm{IV}}=\mathrm{O}$, the first model compound $\mathrm{I}$ : a structure of oxoiron(IV)TMP radical cation; $\mathbf{b}$ depiction of $\left(\mathrm{TMP}^{+\cdot}\right) \mathrm{Fe}^{\mathrm{IV}}=\mathrm{O}$ from reference 56 and its Mössbauer spectrum, which indicates high-valent iron

an $S=3 / 2$ system, while the $\beta$-pyrrole protons were observed at very high field, $\delta=-27$. The Mössbauer spectrum displayed a characteristic doublet at $0.05 \mathrm{~mm} / \mathrm{s}$ with quadrupolar splitting $\Delta E_{\mathrm{q}}=1.49 \mathrm{~mm} / \mathrm{s}$ [53]. This complex, as well as HRP compound I, was shown to have a short $\mathrm{Fe}=\mathrm{O}$ bond distance of $1.65 \AA$ by EXAFS spectroscopy [54], cementing the assignment of I as an oxoiron(IV) porphyrin cation radical. Significantly, I showed high oxygen transfer reactivity towards olefins, affording epoxides even at low temperature. Notably, the generation of I with peroxyacids in the presence of ${ }^{18} \mathrm{O}$-water led to significant incorporation of the oxygen label into the epoxide products, indicating fast iron-oxo exchange with water: $\left(\mathrm{TMP}^{++}\right) \mathrm{Fe}^{\mathrm{IV}}=\mathrm{O}+\mathrm{H}_{2}^{18} \mathrm{O} \leftrightarrows\left(\mathrm{TMP}^{++}\right) \mathrm{Fe}^{\mathrm{IV}}={ }^{18} \mathrm{O}+\mathrm{H}_{2} \mathrm{O}$. Hydroxylation of even the strong $\mathrm{C}-\mathrm{H}$ bonds of alkanes was also achieved in those initial studies $[55,56]$. It was observed at that time that the hydroxylation product distribution was very sensitive to the steric bulk of the iron porphyrin meso-substitution. This regioselectivity led us to propose that hydrogen atom abstraction from the substrate occurred through the singly occupied ferryl $\pi^{*}$ antibonding orbitals as depicted in the original, hand-drawn format (Fig. 5b).

Reactive high-valent metal-oxo porphyrins of manganese, chromium, and ruthenium have also been isolated and characterized [55, 57-61]. In particular, oxomanganese(V) porphyrin complexes displayed very high rates for oxygen transfer reactions in aqueous solution [62, 63]. Recently, the compound I analog of a highly electron-withdrawing, water-soluble iron porphyrin, $\left[4-\mathrm{TMPyP}^{+}\right] \mathrm{Fe}^{\mathrm{IV}}=\mathrm{O}$, was prepared and shown to exhibit rate constants comparable to

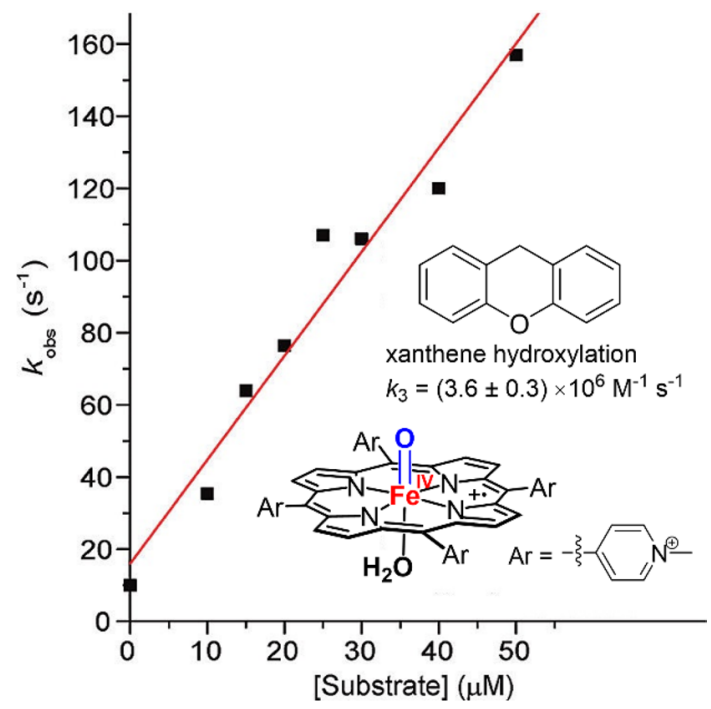

Fig. 6 A highly reactive model ferryl porphyrin cation radical of an electron-withdrawing iron porphyrin, ref 64

those of cytochrome $\mathrm{P} 450$ for benzylic $\mathrm{C}-\mathrm{H}$ hydroxylation (Fig. 6) [64].

In spite of these close analogies, the lack of direct spectroscopic and kinetic characterization of a $\mathrm{P} 450$ compound I led to proposals of other intermediates such as iron(V)oxo and ferric hydroperoxo as alternative hydrogen-abstracting intermediates for P450s [65-67]. The long-sought P450 compound I was finally captured in 2010. Using freezequench techniques, Rittle and Green successfully obtained the compound I of CYP119 in high yield [68]. The nearzero chemical shift of the iron in the Mössbauer spectrum, the doublet electronic ground state signaled by the EPR spectrum, the weakened and blue-shifted Soret band in the UV, and a long-wavelength absorbance in the visible near $700 \mathrm{~nm}$ explicitly showed that CYP119-I is indeed an oxoiron(IV) porphyrin cation radical. These spectral signatures are reminiscent of those found in the first synthetic ferryl porphyrin cation radical (species I, Fig. 5) as well as the reactive [4-TMPyP $\left.{ }^{+}\right] \mathrm{Fe}^{\mathrm{IV}}=\mathrm{O}$. CYP119-I was highly reactive toward unactivated $\mathrm{C}-\mathrm{H}$ bonds with an apparent rate constants in the range of $10^{4}-10^{7} \mathrm{M}^{-1} \mathrm{~s}^{-1}$. In 2012, a second reactive compound I was characterized by our group for the extracellular heme-thiolate aromatic peroxygenase from Agrocybe aegerita (AaeAPO) [69, 70]. These newly discovered fungal peroxygenases, now called unspecific peroxygenases (UPO), are only distantly related to chloroperoxidase according to their amino acid sequences, and completely unrelated to CYP enzymes, although the proximal ligand environment, including peptide $\mathrm{N}-\mathrm{H}$ hydrogen bonding to the heme-thiolate sulfur, is very similar [71]. AaeAPO-I showed fast rate constants for substrate hydroxylations for $\mathrm{C}-\mathrm{H}$ bonds up to $100 \mathrm{kcal} / \mathrm{mol}$ in the 


$$
D_{\mathrm{O}-\mathrm{H}}(\mathrm{cpd} \mathrm{II})=23.06 \times E^{\mathrm{o}}(\mathrm{cpd} \mathrm{I})+1.37 \times \mathrm{p} K_{\mathrm{a}}(\mathrm{cpd} \mathrm{II})+\mathrm{C}
$$

(a)

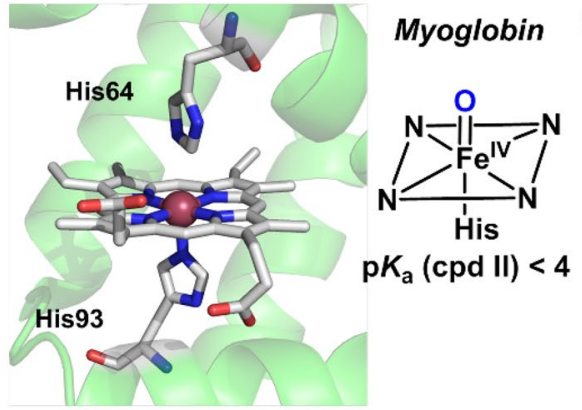

(c)

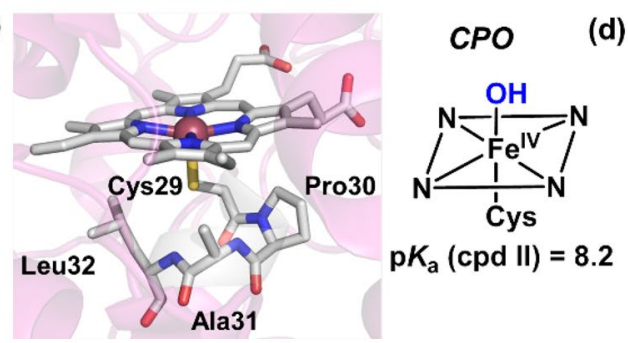

(b)

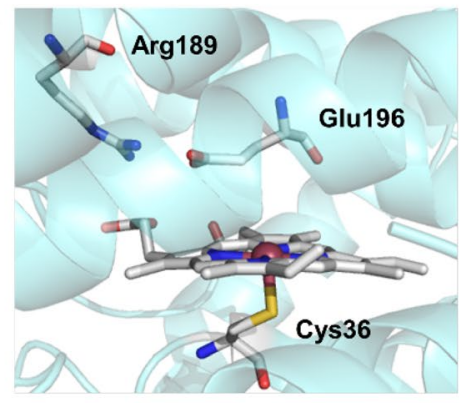

(d)

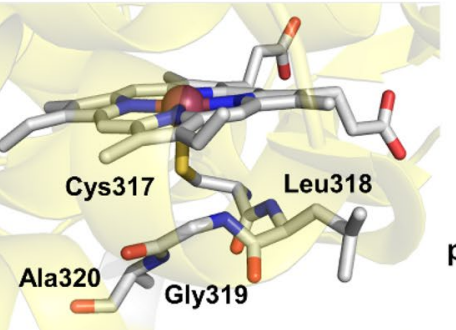

\section{AaeAPO}

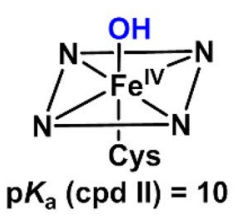

P450 (CYP119)

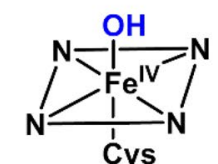

$\mathrm{pK} K_{\mathrm{a}}(\mathrm{cpd} \mathrm{II})=\mathbf{1 2 . 0}$
Fig. 7 Equation 1 shows the Bordwell equation that relates the newly formed $\mathrm{FeO}-\mathrm{H}$ bond energy to its $\mathrm{p} K_{\mathrm{a}}$ and redox potential via a Hess cycle. $\mathrm{C}$ is a constant depending on the solvent and the electrode. For aqueous solution and normal hydrogen electrode, the value of $\mathrm{C}$ is $57.6 \mathrm{kcal} / \mathrm{mol}$. Figure $2 \mathrm{a}-\mathrm{d}$ shows the active site structures and $\mathrm{p} K_{\mathrm{a}} \mathrm{s}$ of compound II for common heme-containing proteins. Active site structures were rendered using following structures: a myoglobin (PDB: 2V1H); b aromatic peroxygenase from Agrocybe aegerita (AaeAPO, PDB: 2YOR); c chloroperoxidase (CPO, PDB: 2J19); d cytochrome P450 (CYP119, PDB: 1IO7). Colors: iron (dark pink), nitrogen (blue), oxygen (red), carbon (silver), sulfur (yellow)

the cleavage of strong $\mathrm{C}-\mathrm{H}$ bonds at biologically viable reduction potentials and reduce damage to the protein scaffold [78, 79]. Indeed, histidine-ligated heme proteins such as myoglobin and horseradish peroxidase appear to have non-basic ferryls with estimated $\mathrm{p} K_{\mathrm{a}}$ less than 4 , consistent with their slow and ineffective oxidative reactivity (Fig. 7a) [79, 80]. The heme-thiolate protein CPO is much more reactive than histidine-ligated heme proteins. The $\mathrm{p} K_{\mathrm{a}}$ of CPO compound II was estimated to be above 8 (Fig. 7b) [81]. Very recently, Green et al. successfully determined the $\mathrm{p} K_{\mathrm{a}}$ values of two P450s, CYP158, and CYP119 [82]. The two enzymes have similarly high compound II $\mathrm{p} K_{\mathrm{a}} \mathrm{s}$ (around 12, Fig. 7c), although they have very different active site environments.

A highly basic compound II ( $\mathrm{p} K_{\mathrm{a}}=10.0$, Fig. $\left.7 \mathrm{~d}\right)$ was also observed for the heme-thiolate aromatic peroxygenase APO described above [83]. Importantly, the reduction potential of APO-I, $1.2 \mathrm{~V}$ with respect to the resting ferric protein, could also be determined through a Nernst equation analysis of its reversible reaction kinetics with chloride and bromide ions. This value allowed for the determination of the individual, one-electron reduction potentials of APO-I and APO-II to be $E_{\text {cpd I/cpd II }}=1.4 \mathrm{~V}$ and $E_{\text {cpd II/ferric }}=0.8 \mathrm{~V}$ at $\mathrm{pH}$ 7.0, and our estimate that the O-H BDE of Cys-S$\mathrm{Fe}^{\mathrm{IV}}-\mathrm{O}-\mathrm{H}$ of $\mathrm{APO}$ is $\sim 100 \mathrm{kcal} / \mathrm{mol}$. What this means is that for APO, and likely $\mathrm{P} 450$ as well, strong aliphatic $\mathrm{C}-\mathrm{H}$ typical metal-oxo species. This effect would allow for 
(a)
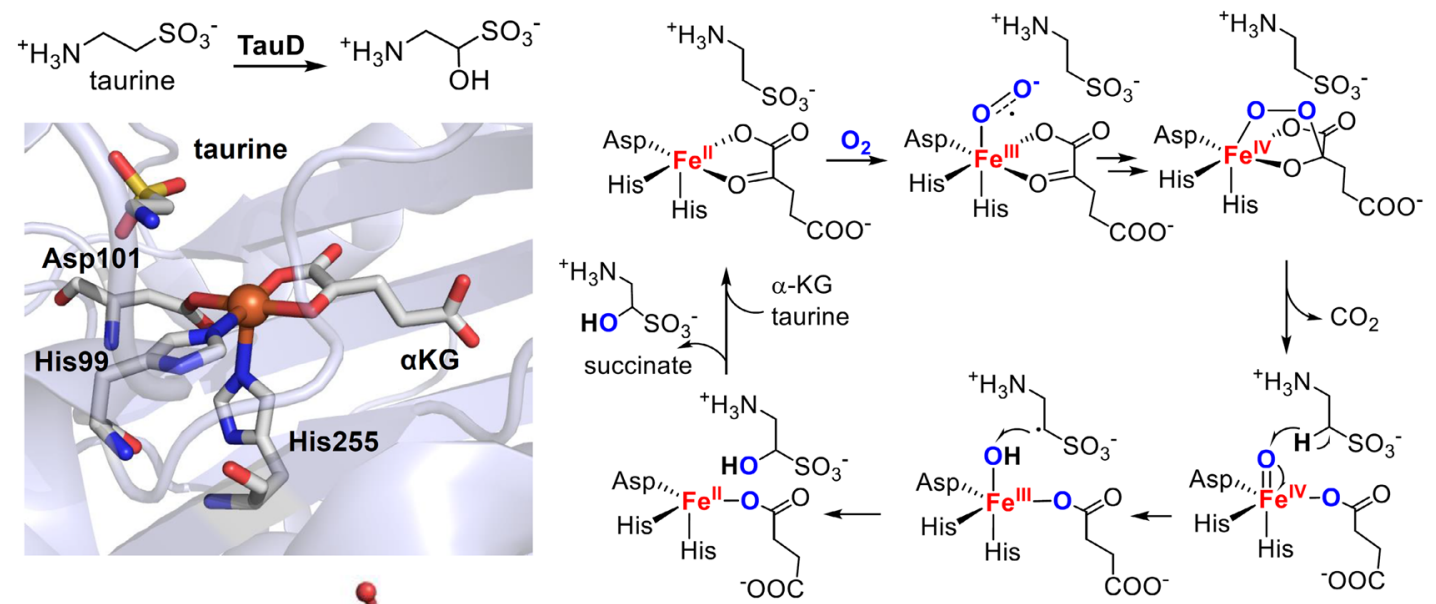

(b)
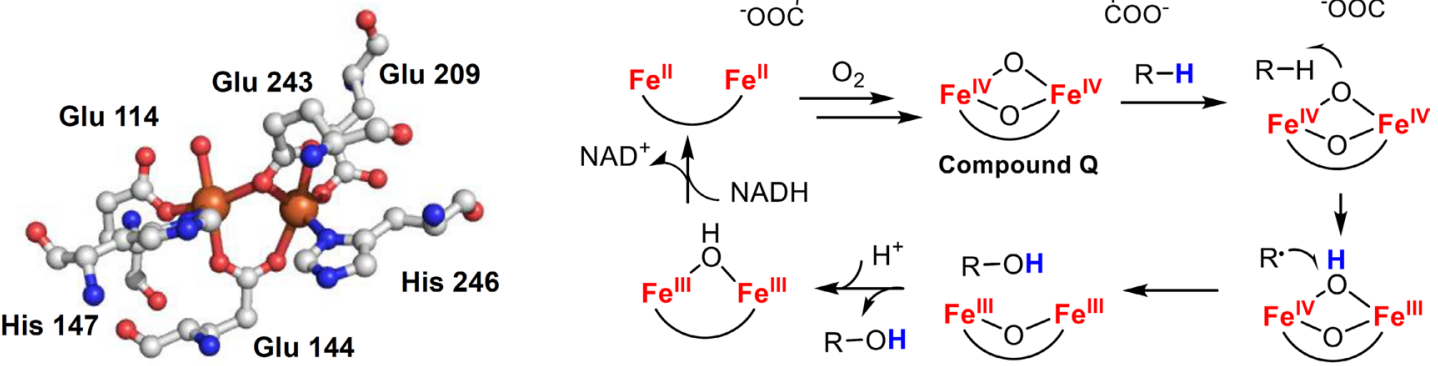

Fig. 8 a Active site structure of a typical $\alpha \mathrm{KG}$ dependent non-heme iron(II) dioxygenase, TauD, (PDB: 1OS7) and the mechanism of taurine hydroxylation catalyzed by TauD. b Active site structure of a representative non-heme diiron hydroxylase, soluble methane

bonds are cleaved by these enzymes rapidly, even though there is little or no driving force for the reaction.

Cytochrome P450 is not the only enzyme that utilizes high-valent iron-oxo intermediates to effect $\mathrm{C}-\mathrm{H}$ activation reactions. Indeed, high-valent iron-oxo complexes are widely present as the reactive intermediates for the oxidative catalysis by iron-containing oxygenases [2, 5, 10]. A notable example is the superfamily of $\alpha$-ketoglutarate $(\alpha \mathrm{KG})$ dependent non-heme iron(II) dioxygenases, which catalyze highly selective aliphatic $\mathrm{C}-\mathrm{H}$ hydroxylations [84]. In the active site of these enzymes, the iron(II) center is coordinated facially by two histidines and one carboxylate $[85,86]$, a motif known as the '2-His-1-carboxylate facial triad'. The consensus mechanism of $\alpha \mathrm{KG}-\mathrm{Fe}(\mathrm{II})$ oxygenases is analogous to that of $\mathrm{P} 450$ s, in which a highvalent oxoiron(IV) intermediate, first formed through $\mathrm{O}_{2}$ activation, abstracts a hydrogen from the substrate [87, 88]. The incipient substrate radical is then captured by a hydroxoferric intermediate, analogous to $\mathrm{P} 450$ compound II, to afford the hydroxylated product (Fig. 8a).

Another example of enzymes that exploit high-valent iron-oxo species for $\mathrm{C}-\mathrm{H}$ activation are the non-heme diiron hydroxylases. The reactive intermediate for this family of enzymes is a bis- $\mu$-oxo-iron(IV) complex called compound Q [89-91]. The compound Q of soluble methane monooxygenase (sMMO) in reduced state (PDB: 1FYZ) and the typical mechanism of $\mathrm{C}-\mathrm{H}$ hydroxylation catalyzed by non-heme diiron hydroxylase. Colors: iron (orange), oxygen (red), nitrogen (blue), sulfur (yellow)

monooxygenase (sMMO) has been well characterized [9193]. Similar intermediates were also proposed for other non-heme diiron enzymes including the $\omega$-hydroxylase AlkB, toluene monooxygenase $(\mathrm{T} 4 \mathrm{moH})$, and xylene monooxygenase (XylM) [89, 94]. Like compound I in P450s, compound Q initiates a hydrogen abstraction/radical rebound sequence to hydroxylate hydrocarbons, most remarkably, even methane with its $104 \mathrm{kcal} / \mathrm{mol} \mathrm{C}-\mathrm{H}$ bonds (Fig. 8b). From these various enzymatic reactions, it is clear that the radical rebound mechanism is a general paradigm in biological $\mathrm{C}-\mathrm{H}$ oxidations catalyzed by ironcontaining oxygenases, uniting the heme and non-heme enzymes.

\section{The intermediacy of substrate radicals during $\mathbf{C}-\mathrm{H}$ activation by iron-containing oxygenases}

The characteristic feature of the radical rebound mechanism is the intermediacy of the substrate radical generated in the initial hydrogen abstraction step. The properties and behavior of the incipient radical (i.e. lifetimes and conformational changes) and physical and chemical characteristics of the radical rebound step (i.e. rate constant and 

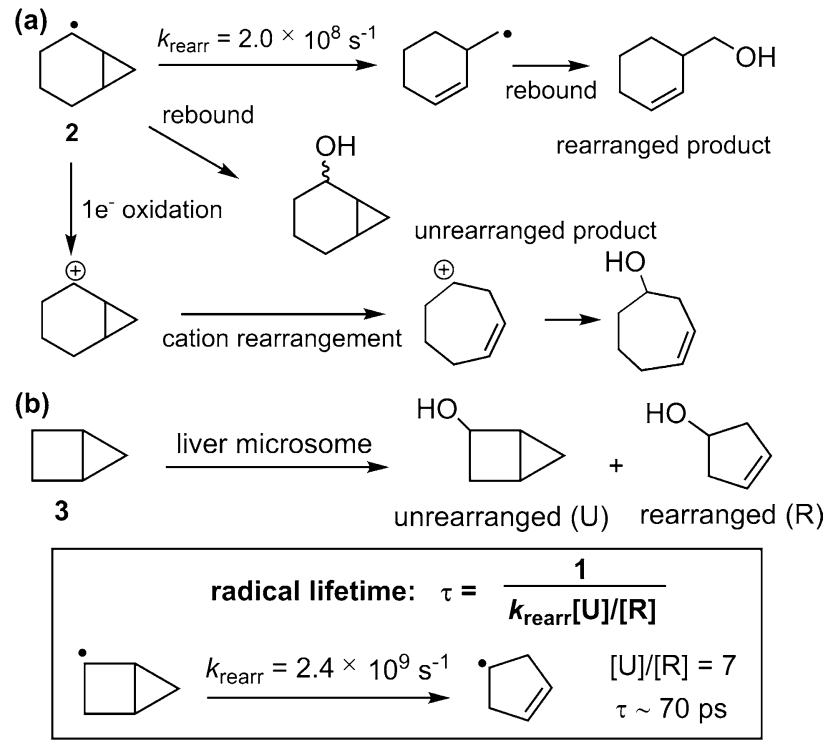

\begin{tabular}{|c|c|c|c|c|c|}
\hline & $\mathrm{P}^{4} 50_{\text {cam }}$ & $\mathrm{P}^{4} 50_{\mathrm{BM} 3}$ & CYP2B1 & CYP2E1 & CYP102 \\
\hline$[U] /[R]$ & 97 & 115 & 319 & 144 & 33 \\
\hline clock & 2 & 2 & 2 & 2 & 4 \\
\hline$\tau(\mathrm{ps})$ & 52 & 44 & 16 & 35 & 38 \\
\hline
\end{tabular}

Fig. 9 a Mechanisms of rearrangement of the 2-norcaranyl radical and cation intermediates. b Oxidation of bicyclopentane catalyzed by liver microsomal P450. c A representative cyclopropane-based radical clock probe and radical lifetimes of common cytochrome P450s

stereoselectivity) greatly influence the reaction outcome and are of crucial importance for the understanding of chemistries involving high-valent iron-oxo complexes. However, the transient nature of the substrate radical and the radical rebound step involving $\left[\mathrm{Fe}^{\mathrm{n}-1}-\mathrm{OH} \cdot \mathrm{R}\right]$ has generally precluded direct mechanistic studies with common kinetic and spectroscopic methods. In this regard, mechanistically diagnostic substrates, which form radicals that undergo changes in stereochemistry or structure after hydrogen abstraction, offer a powerful tool to study the intermediate radical and the rebound step [95].

The first radical rearrangement studies to probe biologically relevant $\mathrm{C}-\mathrm{H}$ hydroxylation used norcarane as a mechanistically diagnostic substrate and manganese porphyrins as the catalyst [55]. Significantly, the 2-norcaranyl radical (2) ring-opens to a primary homoallylic radical, while the corresponding cation affords the more substituted cycloheptenyl cation (Fig. 9a). The switch in reaction pathways is caused by a kinetic preference for cyclopropyl $\mathrm{C}-\mathrm{C}$ bond cleavage to afford the less stable primary carbon radical, while for the cationic pathway thermodynamics prevail. Ortiz de Montellano and Stearns applied this type of substrate rearrangement probe to cytochrome P450s [96]. They found that bicyclo[2.1.0]pentane (3) was oxidized by rat liver microsomes containing the $\mathrm{P} 450$ enzyme to a mixture of ring opened and unrearranged hydroxylation products in a ratio of 1:7 (Fig. 9b). Given the known ring-opening rearrangement rate constant of $2.4 \times 10^{9} \mathrm{~s}^{-1}$ for 2-bicyclopentanyl radical [97], a first-order rate constant of $1.4 \times 10^{10} \mathrm{~s}^{-1}$ and an intermediate radical lifetime of $\sim 70 \mathrm{ps}$ were inferred for the oxygen rebound step. After this work, there were extensive radical clock analyses on P450s especially using norcarane [32, 98]. Norcarane is a very informative probe because the slower radical rearrangement rate of $2 \times 10^{8} \mathrm{~s}^{-1}$ and, as discussed above, radical and cation processes afford different products (Fig. 9a) [99]. The application of norcarane to a variety of P450s gave radical rebound rates in the range between $10^{10}$ and $10^{11} \mathrm{~s}^{-1}$ corresponding to radical lifetimes also in the picosecond regime [100]. This timing is sufficient for many molecular vibrations and rotations but is too short to allow radical diffusion out of the enzyme active site. The yield of the cation-derived product cycloheptenol varied with enzymes but was generally small. A likely origin of the carbocation intermediate is an electron-transfer oxidation of the incipient carbon radical that competes with the radical oxygen rebound, as will be discussed further below. In addition to norcarane, other radical clocks such as alkyl-substituted cyclopropanes have also been employed to study the mechanism of P450-catalyzed oxidations. Rebound rate constants between $10^{10}$ and $10^{11} \mathrm{~s}^{-1}$ were generally obtained (Fig. 9c), despite some cases for which rate constants above $10^{12} \mathrm{~s}^{-1}$ were inferred with 'ultrafast' clocks based on aryl-substituted cyclopropanes [101]. Possible causes of this inconsistency include variations in the intimacy of the radical cage pair, the involvement of different spin states of the rebounding intermediate, and differences in the environment experienced by the substrate radicals within the confined space of $\mathrm{P} 450$ active site [1].

Similar radical-clock studies have also been performed on a variety of non-heme iron-containing enzymes that showed large variations in substrate radical lifetimes (Table 1). For instance, radical lifetimes of diiron-containing soluble methane monooxygenases (sMMO) [89, 90, 102, 103], toluene 4-monooxygenase $(\mathrm{T} 4 \mathrm{moH})$ [104, 105], and alkane hydroxylase alkB [106-108], were determined to be $20,263 \mathrm{ps}$, and $1 \mathrm{~ns}$, respectively. A very long radical lifetime (11 ns) was observed for monooxygenation reactions catalyzed by naphthalene dioxygenase (NDO), which belongs to the family of Rieske dioxygenases [109]. Such variations in radical lifetimes were also observed in synthetic model compounds. i.e. with the norcarane radical clock, hydroxylations catalyzed by synthetic iron porphyrins showed radical lifetimes in the order of tens to 
Table 1 Typical radical lifetimes of non-heme iron enzymes and synthetic metalloporphyrins determined by norcarane

\begin{tabular}{lllllll}
\hline & T4moH & sMMO & AlkB & NDO & Mn(TMP)OAc & Fe-4-TMPyP \\
\hline$[U] /[R]$ & 19 & 240 & 5.3 & 0.34 & 15.2 & 6 \\
$\tau$ & $263 \mathrm{ps}$ & $20 \mathrm{ps}$ & $1 \mathrm{~ns}$ & $11 \mathrm{~ns}$ & $330 \mathrm{ps}$ & $81 \mathrm{ps}^{\mathrm{a}}$ \\
\hline
\end{tabular}

a Tetramethylcyclopropane (TMCP) was used as radical clock substrate hundreds of picoseconds [110], while reactions catalyzed by manganese porphyrins exhibited radical lifetimes in the nanosecond regime [55].

The large range of radical lifetimes for various enzymes and synthetic model compounds highlights the intricacy and inner diversity of the transient radical rebound step of $\left[\mathrm{Fe}^{\mathrm{n}-1}-\mathrm{OH} \cdot \mathrm{R}\right]$. A fundamental question to ask is what factors control the radical lifetimes and rebound rate. From a thermodynamic perspective, radical rebound is a one-electron reduction process to the metal center. It is therefore not surprising that the metal center as well as the oxidation of the substrate radical intermediate would affect the radical rebound rate. This notion is well illustrated by the over tenfold increase in radical lifetimes for manganese porphyrin-catalyzed aliphatic hydroxylations compared to the reactions catalyzed by iron porphyrins (Table 1) [55, 110]. In sharp contrast, radical intermediates were not observed for $\mathrm{C}-\mathrm{H}$ hydroxylations catalyzed by ruthenium porphyrins $[110,111]$. Such variations in rebound behavior likely result from the differences in oxidation potentials, electronic configurations, as well as the relative energetics of different spin states of the rebounding intermediates [111-117].

Further insights are found by considering the frontier orbital interactions during the rebound encounter [118, 119]. Most of our understanding regarding this aspect comes from computational studies. A revealing notion gained from such studies is the possible involvement of multiple spin states and energetic surfaces for oxidations catalyzed by paramagnetic iron-oxo intermediates, which was first suggested by Shaik and his colleagues in the density functional theory (DFT) analysis of methane hydroxylation by a ferryl-porphyrin cation radical [120]. They found that the ferryl intermediate had two nearly isoenergetic electronic configurations, doublet and quartet, and thus the $\mathrm{C}-\mathrm{H}$ abstraction and radical rebound could occur along either a high-spin (HS) or a low-spin (LS) trajectory (Fig. 10). Green et al. have shown that P450 compound I adopts a low spin $S=1 / 2$ state [68]. Intriguingly, $S=3 / 2$ spin states were generally shown for compound I of iron porphyrin model compounds [121]. These experimental findings suggest a facile interconversion between the doublet and quartet spin states of compound I. While the two pathways showed similar energy barriers for the $\mathrm{C}-\mathrm{H}$ abstraction, the HS pathway exhibited a larger barrier for the radical recombination step. In both pathways,

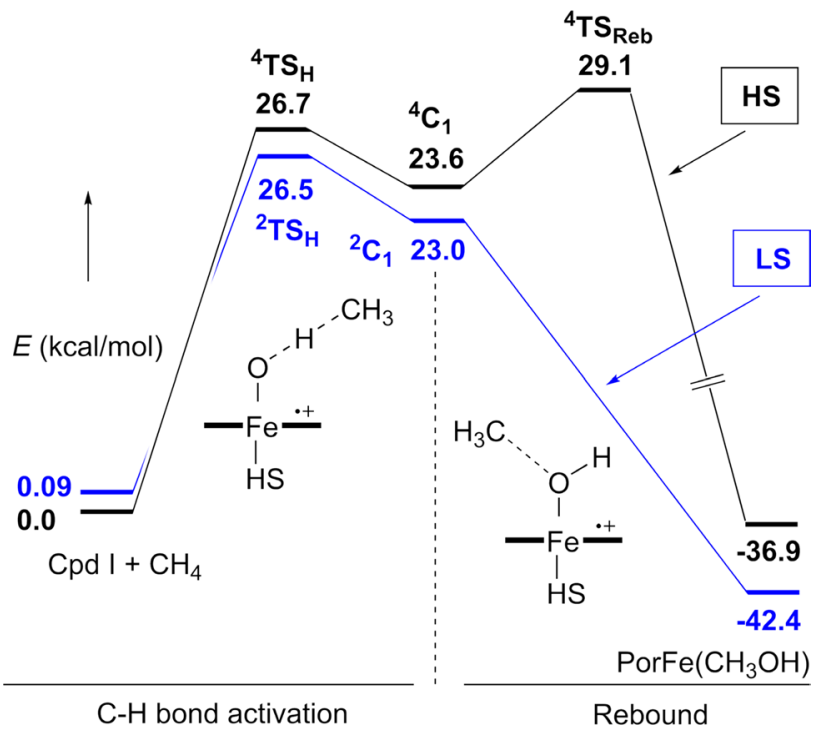

Fig. 10 Energy profile and reaction coordinate for the methane hydroxylation by a ferryl-porphyrin cation radical. The figure is adapted from Ogliaro et al. [120]

the rebound intermediate $\mathrm{Fe}^{\mathrm{IV}}-\mathrm{OH}$ adopted an $S=1$ spin state. On the LS surface, the electron of the substrate radical is predicted to interact with the singly-occupied iron $d_{\mathrm{xz}}$ (or $d_{\mathrm{yz}}$ ) orbital as in Fig. 5b, whereas in the HS pathway, the electron transfers into a higher-energy, unoccupied $d_{z} 2$ orbital, giving rise to the larger rebound barrier for rebound along the HS surface. Recently, Shaik further applied this multi-state analysis to a number of non-heme metal-oxo systems including $\mathrm{Mn}^{\mathrm{IV}} \mathrm{O}, \mathrm{Fe}^{\mathrm{IV}} \mathrm{O}, \mathrm{Cr}^{\mathrm{IV}} \mathrm{O}, \mathrm{Fe}^{\mathrm{V}} \mathrm{O}$, and $\mathrm{Ru}^{\mathrm{IV}} \mathrm{O}$. In these cases, the energy barriers of the rebound step were also dependent upon the spin states of the pathways [122]. The calculated rebound barriers of non-heme complexes were much higher than that of the heme intermediate in $\mathrm{P} 450 \mathrm{~s}$. This result is consistent with the long radical lifetime measured for the non-heme iron dioxygenases and may arise from the lower oxidation state of the rebound intermediate $\left(\mathrm{Fe}^{\mathrm{III}}\right)$ in non-heme iron complexes.

In addition to the intrinsic properties of the rebound intermediates, another important, and often overlooked factor that affects the rebound step is the cage effect. After the initial hydrogen atom abstraction, the incipient substrate radical and rebound intermediate comprise a caged radical pair $[\mathrm{Fe}-\mathrm{OH} \cdot \mathrm{R}]$. We note that weak interactions between the substrate radical and the iron center at this 
stage would facilitate spin state interconversions for the ensemble. Another important feature of such caged radical species is the competition between the in-cage radical recombination and the diffusive cage escape. In an enzyme active site a water molecule, or a protein functional group, can insert itself between the substrate radical and the metal center as in $\left[\mathrm{Fe}-\mathrm{OH} \cdots \mathrm{OH}_{2} \cdot \mathrm{R}\right]$. There is abundant photophysical evidence for competitive cage-escape and recombination as stochastic events in radical reactions since their initial discovery in 1930s [123]. A compelling example is the homolytic cleavage of carbon-cobalt bond in $5^{\prime}$-deoxyadenosylcobalamin (coenzyme $\mathrm{B}_{12}$ ) to form cobalt(II)cobalamin and an adenosyl radical, which is important for the biological functions of coenzyme $\mathrm{B}_{12}$-dependent mutase enzymes. Time-resolved spectroscopic studies showed that the initial radical pair formed after $\mathrm{Co}-\mathrm{C}$ bond homolysis in adenosylcobalamin undergoes in-cage radical recombination and cage escape both at approximately $10^{9} \mathrm{~s}^{-1}$, clearly indicating a competition between the two processes [124-126].

The realization of the significant influence of cage effects in radical rebound processes came from our studies of synthetic heme-model compounds. In 1979, we reported the first synthetic iron porphyrin system that effected stereospecific alkane hydroxylation and olefin epoxidation [127]. Further examination of this reaction showed that in the presence of a radical trap, bromotrichloromethane, an $18 \%$ yield of the bromination trapping product was obtained [56]. This result clearly indicated the presence of the cage escaped substrate radical that had encountered $\mathrm{BrCCl}_{3}$ in solution.

The competition between cage escape and in cage recombination would offer an explanation to an enigma observed during the radical clock analysis of alkB, in which radical clock substrates with different rearrangement rate constants gave substantially different radical lifetimes (Fig. 11a) [107]. As shown in Fig. 11, three radical clocks, bicyclopentane, norcaranane, and bicyclo[3.1.0]hex-2-ane showed similar ratios of rearranged to unrearranged products $(R / U)(1.6,1.6$, and 4.7$)$, corresponding to apparent radical lifetimes of $0.78,7.8$, and $170 \mathrm{~ns}$. These seemingly contradictory and counterintuitive results can be accommodated by a mechanism involving the diffusive cage escape of the substrate radical within the rather long enzyme active site to a solvent-separated radical pair, $\mathrm{RP}_{\mathrm{ss}}$ (Fig. 11b) [108]. If the cage escape of the substrate radical occurs at a rate constant $\left(k_{\mathrm{e}}\right)$ comparable to the rebound rate $\left(k_{\mathrm{R}}\right)$, then for clocks with radical rearrangement constants $\left(k_{\mathrm{r}}\right)$ slower than $k_{\mathrm{e}}$, the $R / U$ ratios would not be much affected by the differences in $k_{\mathrm{r}}$ but reflect the "caging efficiency" $k_{\mathrm{e}} / k_{\mathrm{r}}$. This effect is analogous to the commonly observed suppression of the kinetic hydrogen isotope effects by strong binding of the substrate. The value of $k_{\mathrm{e}}$ is not expected to
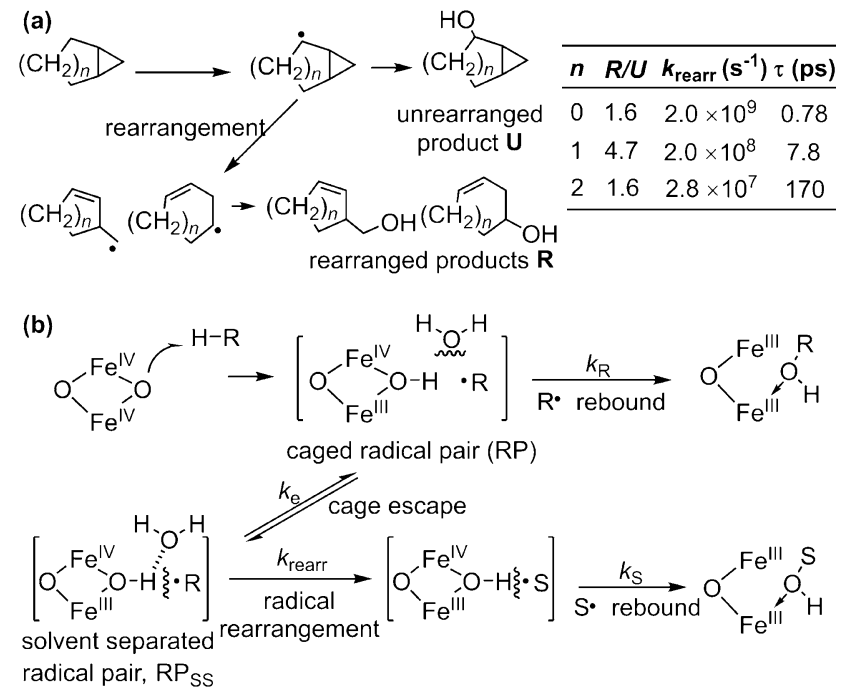

Fig. 11 a Oxidation of radical clock probes with different rearrangement rate constants by non-heme diiron hydroxylase AlkB. b Schematic illustration of geminate recombination and cage escape. The scheme is adapted from Austin et al. [107]

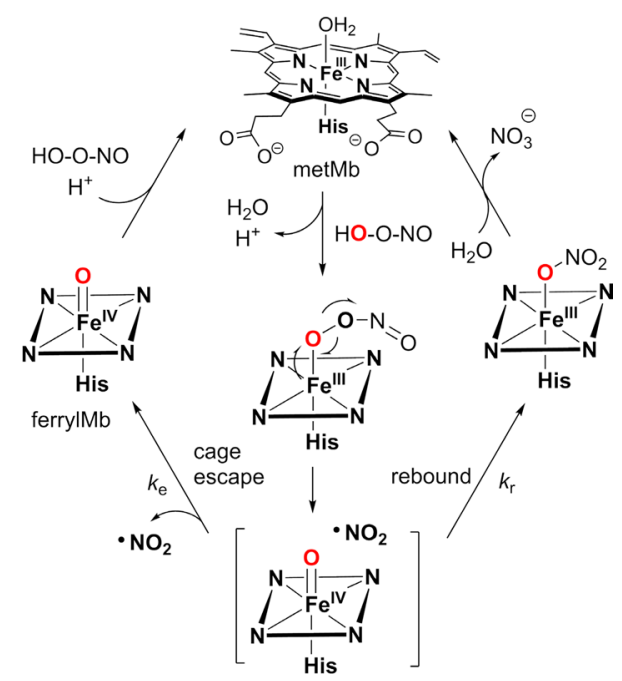

Fig. 12 Catalytic cycle of metMb-catalyzed peroxynitrite decomposition

be constant because it will be substantially affected by the environment, such as viscosity of the solvent, tightness of the radical cage, steric and electronic environment within the active site and associative interactions of the substrate with the enzyme. An example is the large effect of substrate concentration on apparent 2-norcaranyl radical lifetime for AlkB. In this case, the presence of additional substrate molecules could displace and reorganize active-site water creating a bulkier hydrophobic environment that reduces $k_{\mathrm{e}}$ and facilitates the recombination of the initial radical pair. An important lesson learned here is that while diagnostic 
substrates can be used to detect the presence of intermediate radicals, the observed $R / U$ ratios do not reflect the rate of rebound step in a simple way.

There are only a few studies on cage escape effects in P450-catalyzed hydroxylations [110]. But the degradation of peroxynitrite catalyzed by myoglobins provides an example to understand the cage escape/recombination processes in the context of the ferryl intermediates of hemeproteins (Fig. 12) [128, 129]. Myoglobins react rapidly with peroxynitrite to form a radical pair of a compound II ferryl intermediate and $\mathrm{NO}_{2},\left[\mathrm{MbFe} \mathrm{IV}^{\mathrm{IV}}=\mathrm{O} \cdot \mathrm{NO}_{2}\right]$. This radical pair can undergo recombination to form $\mathrm{Fe}^{\mathrm{III}}$-heme and nitrate with rate constant $k_{\mathrm{r}}$, or $\mathrm{NO}_{2}$ can diffuse away from the distal heme site with rate constant $k_{\mathrm{e}}$. One manifestation of freely diffusing $\mathrm{NO}_{2}$ in this scenario is to induce tyrosine nitration elsewhere (i.e. in protein scaffold). This process is reminiscent of the recombination and escape events of deoxymyoglobin with $\mathrm{O}_{2}, \mathrm{CO}$, and NO. The formation of $\mathrm{MbFe}^{\mathrm{IV}}=\mathrm{O}$ was directly observed in these studies by stopped-flow spectrophotometry and a chemical trap, fluorescein, was used to capture the freely diffusing $\mathrm{NO}_{2}$. Based on these measurements, kinetic simulations revealed $10 \%$ cage escape of $\mathrm{NO}_{2}$ and $k_{\mathrm{e}} / k_{\mathrm{r}}=0.10$. Curiously, the reaction of oxymyoglobin with $\mathrm{NO}$, which could have afforded the same peroxynitrito-iron(III) intermediate, did not afford detectable intermediates [130].

Very recently, Shaik and Nam have examined the cage escape/radical rebound processes for a number of nonheme metal-oxo systems [122]. They found that cage escape pathways generally showed low calculated energy barriers that could well compete with the in-cage radical recombination processes. In several cases, such as $\left[\mathrm{Mn}^{\mathrm{IV}} \mathrm{O}(\mathrm{Bn}-\mathrm{TPEN})\right]^{2+}$ and $\left.\left[\mathrm{Fe}^{\mathrm{IV}} \mathrm{O}(\mathrm{Bn}-\mathrm{TPEN})\right]\right]^{2+}$ (BnTPEN $=N$-benzyl- $N, N^{\prime}, N^{\prime}$-tris(2-pyridylmethyl)-1,2ethylenediamine), radical cage escape was found to be the preferred pathway and the diffusing radicals could be trapped by radical scavengers such as $\mathrm{CCl}_{3} \mathrm{Br}, \mathrm{N}$-bromosuccinamide, or $\mathrm{O}_{2}$ under aerobic conditions [131-134].

\section{Radical rebound mechanism: a reaction manifold for versatile biotransformations other than oxygenation}

The stepwise events of hydrogen abstraction and radical recombination in the rebound mechanism represents a general strategy exploited by nature to perform controllable radical reactions. As discussed in the previous section, the behavior of the incipient substrate radical is highly tunable. As such, the initial substrate radical can be employed in a variety of radical processes and lead to different reaction outcomes. In this context, oxygen rebound of substrate radicals to form a $\mathrm{C}-\mathrm{OH}$ bond represents just one type of possible reactions enabled by the radical rebound mechanism. Indeed, nature has found ways to manipulate the behavior of the incipient radicals for chemistries other than oxygen rebound. Early examples include prostaglandin $\mathrm{H}$ synthase and lipoxygenase, in which incipient substrate radicals are trapped by oxygen to afford the hydroperoxy products (Fig. 13, pathway E). In these cases there are discrete oxygen-binding pockets within the protein that control the substrate radical rebound to a nearby oxygen molecule.

In addition to these two enzymes, there are numerous examples described during the past decade highlighting the versatile reactions that incipient substrate radicals could participate. For example, diversion of the rebound intermediate to form olefins can be seen as a hydrogen atom rebound to the $\mathrm{Fe}^{\mathrm{IV}}-\mathrm{OH}$ [32]. Another example is the conversion of fatty acids to terminal alkenes catalyzed by cytochrome $\mathrm{P} 450 \mathrm{OleT}_{\mathrm{JE}}$ (Fig. 14). Since its discovery in 2011, this biotransformation has garnered considerable attention due to its potential applications in biofuel and fine chemical synthesis [135-137]. The studies of Makris et al. showed that the mechanism of $\mathrm{OleT}_{\mathrm{JE}^{-} \text {-catalyzed decarbox- }}$ ylation involved an initial hydrogen abstraction by $\mathrm{OleT}_{\mathrm{JE}}$ compound I as in P450-catalyzed hydroxylations at the $\beta$ carbon relative to the carboxyl group [138, 139]. This result is intriguing, as it suggests that the usual oxygen rebound step must be inhibited in the case of OleT and the incipient radical is redirected to a $\mathrm{C}-\mathrm{C}$ bond scission pathway, presumably involving single electron transfer from substrate radical to compound II and subsequent loss of $\mathrm{CO}_{2}$ to form $\mathrm{C}=\mathrm{C}$ bond. Such electron transfer processes to form substrate cation intermediate have also been reported recently for CYP161C2 (PntM), which catalyzes an oxidative rearrangement reaction that converts pentalenolactone $\mathrm{F}$ to pentalenolactone (pathway C, Fig. 13) [140].

Computational studies by de Visser et al. also suggested a slow-down of the radical rebound for OleT [141]. An $8 \mathrm{kcal} / \mathrm{mol}$ energy barrier was estimated for the oxygen rebound of substrate radical to $\mathrm{OleT}_{\mathrm{JE}}$ compound II, while the energy barrier of the decarboxylation pathway was estimated to be below $1 \mathrm{kcal} / \mathrm{mol}$. The calculation also suggested that hydrogen bonding interactions within the P450 OleT $_{\mathrm{JE}}$ active site are essential for the destabilization of the oxygen rebound.

An analogous example to $\mathrm{P} 450 \mathrm{OleT}_{\mathrm{JE}}$-catalyzed decarboxylation is the iconic side chain $\mathrm{C}-\mathrm{C}$ bond scission reaction catalyzed by cytochrome $\mathrm{P} 450_{\mathrm{SCC}}$, which converts cholesterol to pregnenolone. $\mathrm{P}^{4} 50_{\mathrm{SCC}}$ first performs two successive hydroxylations of cholesterol to form $20 \alpha, 22(R)$ dihydroxycholesterol (DHC) (Fig. 15a). In the third step, $\mathrm{P} 450_{\mathrm{SCC}}$ compound I abstracts the hydrogen from the $\mathrm{C} 22$ hydroxyl group to form a C22-oxy radical and compound II. The C22-oxy radical then undergoes $\mathrm{C} 20-\mathrm{C} 22$ bond 


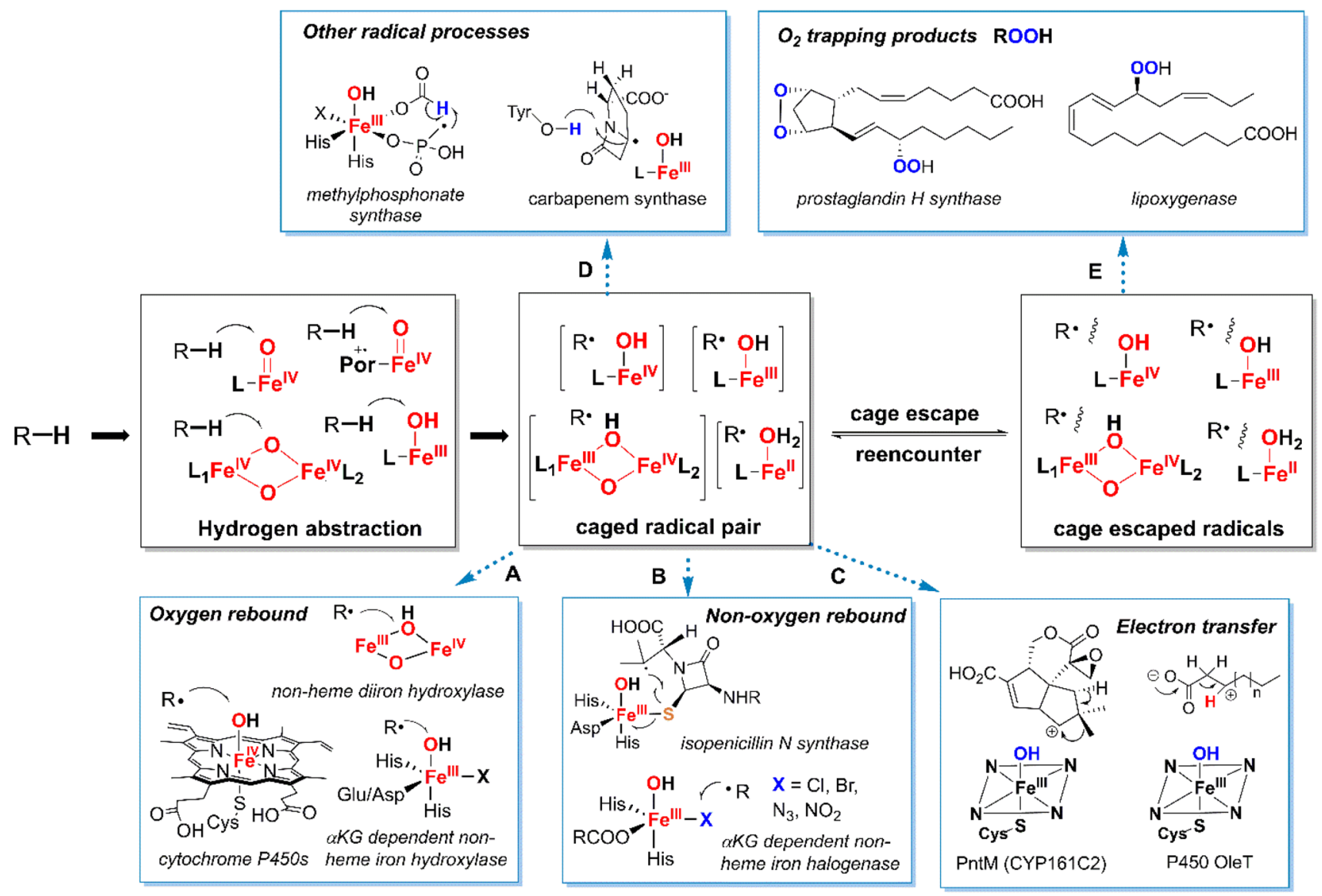

Fig. 13 Generation of the radical pair via hydrogen atom abstraction and the various reaction outcomes depending on the behavior of the radical pair

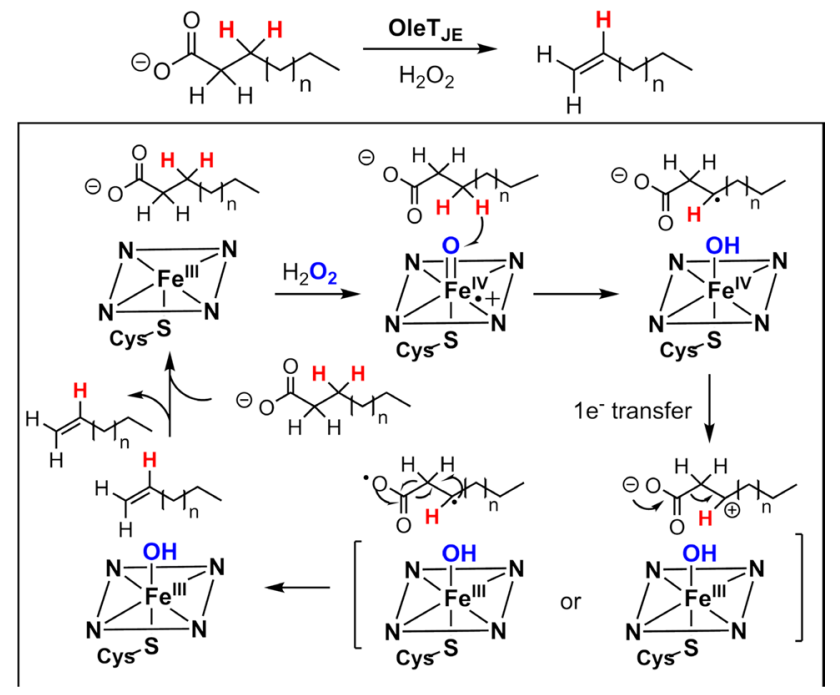

Fig. 14 Oxidative decarboxylation catalyzed by $\mathrm{OleT}_{\mathrm{JE}}$

homolysis to afford isocaproaldehyde and a C20 ketyl radical that recombines with compound II to afford pregnenolone [142]. Recent reevaluation of the activity of steroid aromatase CYP19A1 also suggests a mechanism involving the redirection of the oxygen rebound (Fig. 15b) [143]. In this mechanism, the radical intermediate generated after the initial hydrogen abstraction undergoes one-electron transfer to form a cation in the A ring of androgen, which subsequently aromatizes to form the estrogen. From these examples, it is clear that the radical pair $[\mathrm{Fe}-\mathrm{OH} \cdot \mathrm{R}]$ generated after the initial $\mathrm{C}-\mathrm{H}$ bond cleavage follows different reaction channels leading to novel reactivities other than oxygenation.

Steering radical rebound is also widely exploited in nonheme iron enzymes. A compelling example is the formation of isopenicillin $\mathrm{N}$ from $\delta$-(L- $\alpha$-aminoadipoyl)-L-cysteinyl-Dvaline (ACV) catalyzed by isopenicillin $\mathrm{N}$ synthase (IPNS) (Fig. 16), which is a key step in the biosynthesis of penicillin and cephalosporin antibiotics [144]. IPNS is a nonheme iron(II)-dependent oxygenase with an active site containing an iron coordinated to a 2-His-1-carboxylate facial triad. The elegant work of Baldwin and co-workers showed that two stages were involved for the formation of isopenicillin $\mathrm{N}$ from ACV [144]. The first stage involves the formation of the $\beta$-lactam ring and an $\mathrm{Fe}^{\mathrm{IV}}=\mathrm{O}$ intermediate. 


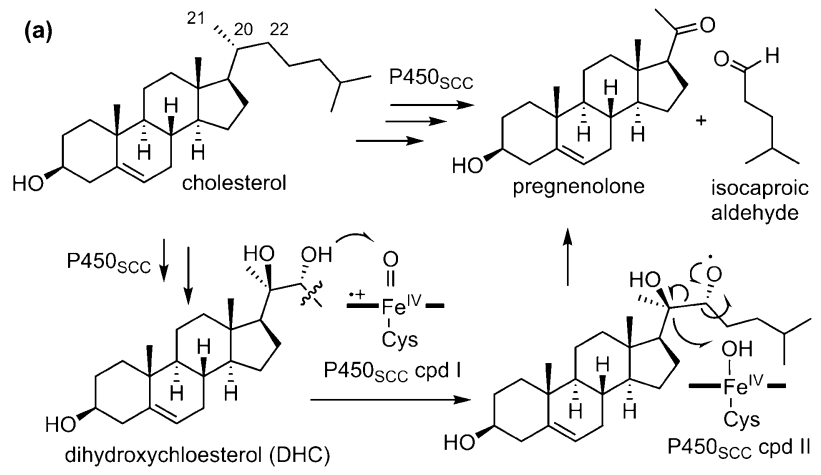

(b)

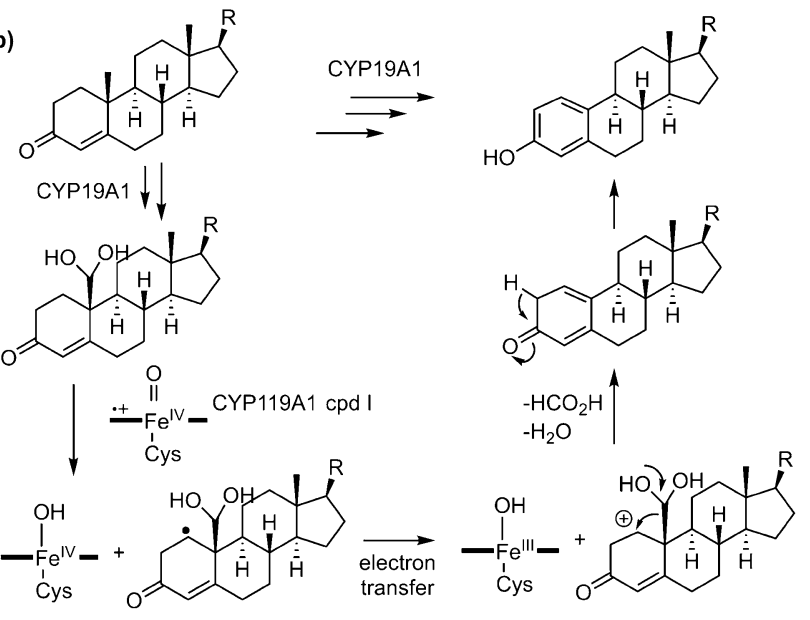

Fig. 15 a Mechanism of the $\mathrm{C}-\mathrm{C}$ scission of DHC catalyzed by $\mathrm{P}^{4} 50_{\text {SCC }}$. b Proposed mechanism of the aromatization step in the conversion of androgens to estrogens catalyzed by CYP19A1

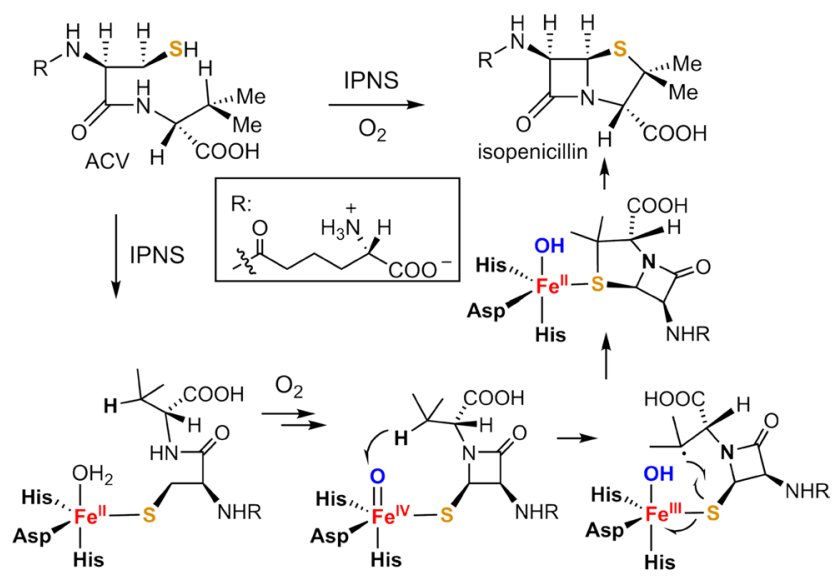

Fig. 16 Mechanism of IPNS-catalyzed formation of isopenicillin from $\mathrm{ACV}$

In the second stage, the $\mathrm{Fe}^{\mathrm{IV}}=\mathrm{O}$ intermediate abstracts a hydrogen from the valinyl $\mathrm{C} 3-\mathrm{H}$ and the resulting $\mathrm{C} 3$ carbon radical recombines with the iron-bound sulfur to generate the thiazolidine ring, a process analogous to the oxygen

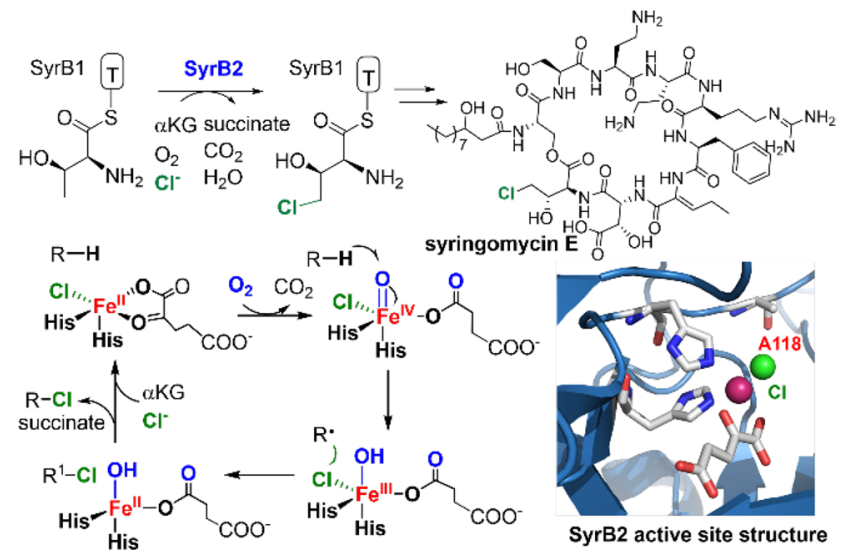

Fig. 17 Mechanism of C-H chlorination catalyzed by SyrB2 (PDB: 2FCT). Colors: iron (magenta), oxygen (red), nitrogen (blue), chlorine (green)

rebound in oxygenation reactions [145]. The involvement of the radical intermediate in this process was illuminated by employing a cyclopropane-containing ACV analog and observation of a rearranged product of the cyclopropylcarbinyl radical [146]. The result that IPNS selectively forms a $\mathrm{C}-\mathrm{S}$ bond rather than $\mathrm{C}-\mathrm{O}$ bond during the radical rebound step is intriguing, as the $\mathrm{C}-\mathrm{S}$ bond is much weaker than the $\mathrm{C}-\mathrm{O}$ bond. The DFT studies by Morokuma et al. on IPNS active-site models showed that, although the formation of hydroxylation product is more thermodynamically favorable, the $\mathrm{C}-\mathrm{S}$ bond formation is kinetically favored as the transition state for sulfur rebound is $3.7 \mathrm{kcal} / \mathrm{mol}$ lower than oxygen rebound barrier [147-149].

Aliphatic $\mathrm{C}-\mathrm{H}$ chlorination reactions catalyzed by $\alpha$-ketoglutarate $(\alpha \mathrm{KG})$ dependent non-heme iron(II) halogenases represent another example of non-oxygen atom rebound. The first $\mathrm{Fe}(\mathrm{II}) / \alpha \mathrm{KG}$ halogenase discovered is the halogenase SyrB2, which catalyzes the $\mathrm{C} 4$ chlorination of threonine appended to the carrier protein SyrB1 (L-Thr-SyrB1) during the biosynthesis of syringomycin E by Pseudomonas syringae (Fig. 17) [150]. Structural studies showed that, in $\mathrm{Fe}(\mathrm{II}) / \alpha \mathrm{KG}$ halogenases, the ferrous center is coordinated to two histidines and a chloride instead of the 2-His-1-carboxylate coordination in a typical $\mathrm{Fe}(\mathrm{II}) / \alpha \mathrm{KG}$ hydroxylase [151]. A conserved alanine or glycine was found at the position of aspartate or glutamate in $\mathrm{Fe}(\mathrm{II}) / \alpha \mathrm{KG}$ hydroxylase which created the space for chloride binding. The mechanism of $\mathrm{Fe}(\mathrm{II}) / \alpha \mathrm{KG}$ halogenases involves a chloroferryl intermediate $\left(\mathrm{Cl}-\mathrm{Fe}^{\mathrm{IV}}=\mathrm{O}\right)$ that abstracts a hydrogen atom to form a substrate radical and a chlorohydroxoferric intermediate $\left(\mathrm{Cl}-\mathrm{Fe}^{\mathrm{III}}-\mathrm{OH}\right)$. The substrate radical then rebounds to the chlorine to afford chlorination product.

The factors leading to the preference for chlorine over hydroxyl transfer during the rebound scenario has attracted 


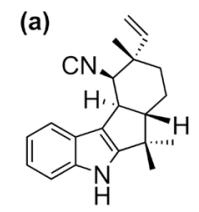

12-epi-fischerindole $\mathrm{U}$

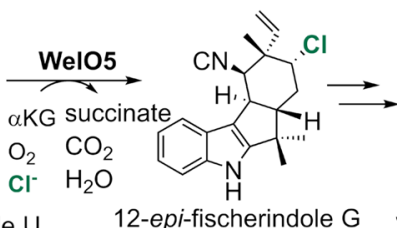

12-epi-fischerindole G

(b)

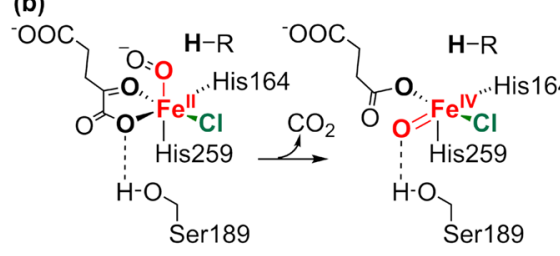

(c)

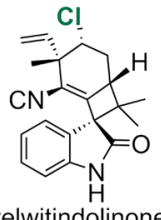

welwitindolinone A isonitrile

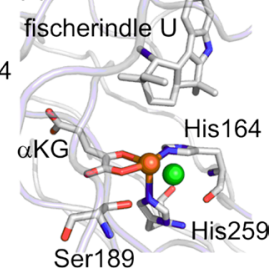

Fig. 18 a C-H Chlorination of 12-epi-fischerindole U catalyzed by the halogenase WelO5. b Relocation of the iron-oxo unit in the formation of oxoiron(IV) intermediate. c Active site structure of WelO5 (PDB: 5IQT). Colors: iron (orange), oxygen (red), nitrogen (blue), chlorine (green)

considerable attention. A number of studies involving spectroscopic and structural analysis as well as reactivity assays using native substrate analogs show that a closer positioning of the substrate radical to the chlorine during the rebound is an important factor in determining the chlorination selectivity [152-158]. Very recently, Boal and Liu obtained the first substrate-bound crystal structure of a carrier protein-independent $\mathrm{Fe}(\mathrm{II}) / \alpha \mathrm{KG}$ halogenase, WelO5, which chlorinates 12-epi-fischerindole $\mathrm{U}$ at the $\mathrm{C} 13$ position [159-161]. The crystal structure indicated a relocation of the oxo unit from the axial position to the equatorial plane defined by the chloride and the $\alpha \mathrm{KG}$, which would draw the oxo group further way from the substrate (Fig. 18). This transition is apparently aided by a hydrogenbonding interaction with the hydroxyl group of Ser189 in the Fe(II) secondary sphere. Mutation of Ser189 to alanine led to an equal portion of hydroxylation and chlorination products.

Chlorination is not the only reaction that $\mathrm{Fe}(\mathrm{II}) / \alpha \mathrm{KG}$ halogenase could effect. Recently, Bollinger and co-workers found that $\mathrm{Fe}(\mathrm{II}) / \alpha \mathrm{KG}$ halogenases could catalyze $\mathrm{C}-\mathrm{H}$ azidation and nitration upon replacing the iron-bound chloride with azide and nitrite [162]. Analogous to the chlorine rebound scenario in halogenases, the incipient radical formed after initial $\mathrm{C}-\mathrm{H}$ abstraction by $\mathrm{Fe}^{\mathrm{IV}}=\mathrm{O}$ recombined with an azidoferric $\left(\mathrm{N}_{3}-\mathrm{Fe}^{\mathrm{III}}-\mathrm{OH}\right)$ or a nitritoferric $\left(\mathrm{NO}_{2}-\mathrm{Fe}{ }^{\mathrm{III}}-\mathrm{OH}\right)$ intermediate to form the $\mathrm{C}-\mathrm{N}_{3}$ or $\mathrm{C}-\mathrm{NO}_{2}$ bond, albeit in modest conversions.

Non-heme iron oxygenases can also catalyze other nonoxygenation reactions by employing substrate radicals in different radical processes. An interesting example is the transformation of 2-hydroxyethylphosphonate (2-HEP) to different products by enzymes sharing a similar mechanism

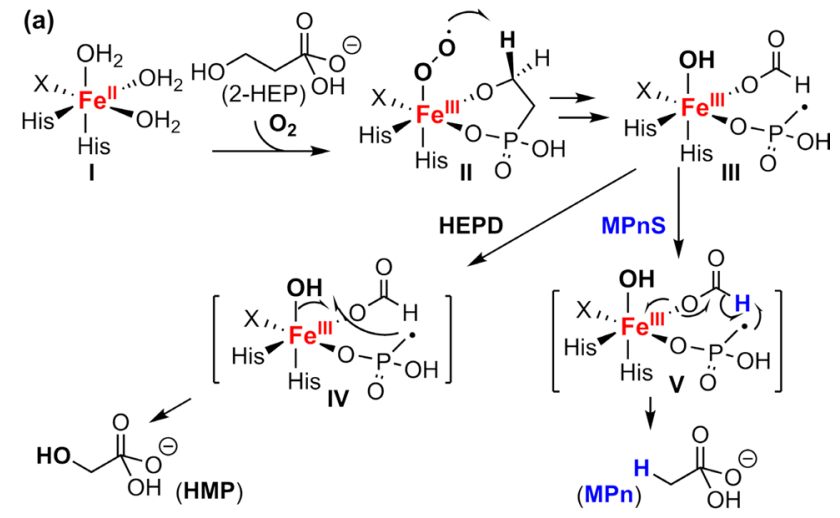

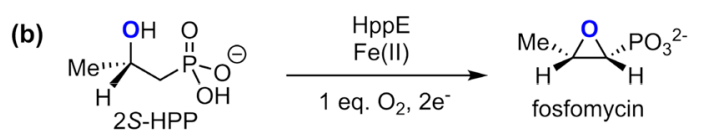

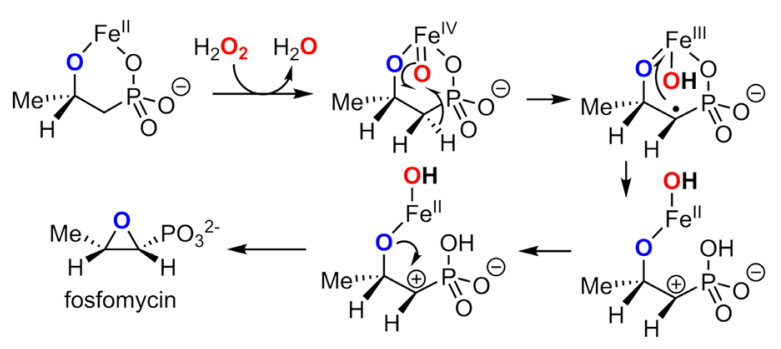

Fig. 19 a Synthesis of HMP and MPn from 2-HEP catalyzed by HEPD and MPnS respectively. b Synthesis of fosfomycin from 2S-HPP catalyzed by HppE

[163-165]. As shown in Fig. 19, 2-HEP can be converted to methylphosphonate (MPn) by MPn synthase (MPnS) or to hydroxymethylphosphonate (HMP) by 2-HEP dioxygenase (HEPD). These two reactions proceed through a common radical intermediate (species III in Fig. 19a). In HEPD, HMP was obtained by the oxygen rebound of the methylphosphonate radical to the $\mathrm{Fe}^{\mathrm{III}}-\mathrm{OH}$ complex (IV in Fig. 19a), whereas in MPnS, the methylphosphonate radical will abstract a hydrogen from the formate to afford MPn (V in Fig. 19a).

An analogous example of HEPD and MPnS is 2-hydroxypropylphosphonate epoxidase (HppE) [166170]. HppE is involved in the biosynthesis of the antibiotic fosfomycin from (S)-2-hydroxypropylphosphonate (2SHPP). In this reaction, an oxoferryl intermediate is formed prior to the epoxide formation step that abstracts the pro- $R$ hydrogen from $\mathrm{C} 1$ of $2 S$-HPP. Subsequent electron transfer from the $\mathrm{C} 1$ radical to $\mathrm{Fe}^{\mathrm{III}}-\mathrm{OH}$ and epoxide ring closure afford the fosfomycin product (Fig. 19b).

In addition to the examples discussed herein, there are a number of other reactions that can be effected by iron oxygenases via controlling the reaction pathways of incipient radicals, including stereoinversion, oxacyclization, carbodesaturation, etc. In another variation of the rebound 
Fig. 20 Comparison between common radical $\mathrm{C}-\mathrm{H}$ functionalizations (a) and those mediated by iron oxygenases and their model compounds (b) (a) Common radical $\mathrm{C}$ - $\mathrm{H}$ functionalizations

$\mathrm{H}$-atom abstractors

Radical trapping agents

RO. RCOO.
RS. ${ }_{\substack{n-2 \\ N}}^{N}-0$.<smiles>CC(=O)NC(=O)NC(C)=O</smiles><smiles>[R]OC=CC(C)=O</smiles>

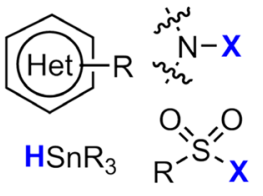

regioselectivity determined by the $\mathrm{C}-\mathrm{H}$ bond strength

limited or no stereoselectivity

(b) Fe-containing oxygenases and model compounds

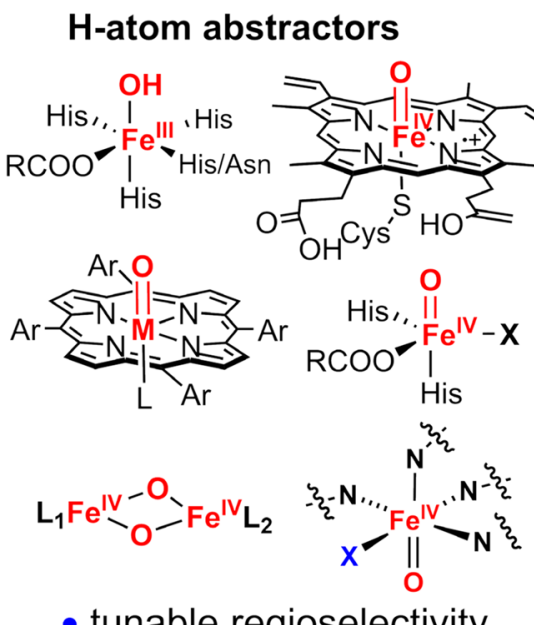

\section{Radical trapping agents}
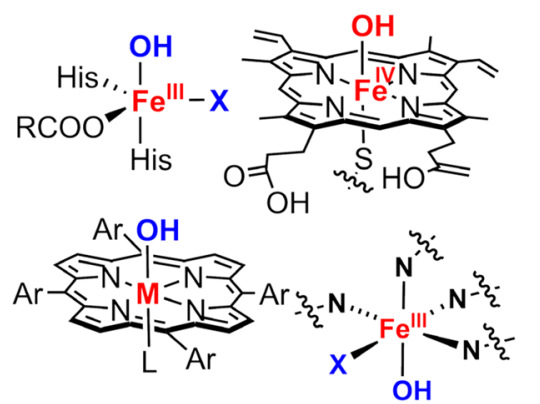

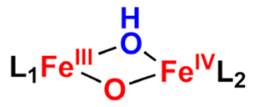

- tunable stereoselectivity spectrum of reactions, aldehyde deformylation by the diiron enzyme $\mathrm{ADO}$ produces alkanes in a process that can be seen as a hydrogen rebound from $\mathrm{Fe}-\mathrm{OH}_{2}$ [171]. These reactions have recently been reviewed by Bollinger and Krebs [172]. The common feature of these biotransformations is the involvement of an initial hydrogen atom abstraction by high-valent iron-oxo intermediates. The desired reaction outcome is achieved by directing the incipient substrate radicals to the corresponding radical reaction pathways such as oxygen rebound, non-oxygen atom rebound, electron transfer, radical cage escape, etc. In this way, nature can achieve a diverse array of $\mathrm{C}-\mathrm{H}$ transformations with molecular oxygen as the oxidant by employing these aspects of the rebound process.

\section{Harnessing the radical rebound mechanism for novel organic radical transformations through biomimetic catalysis}

The direct functionalization of aliphatic $\mathrm{C}-\mathrm{H}$ bonds remains one of the grand challenges for the chemical catalysis community [173]. Activation of aliphatic $\mathrm{C}-\mathrm{H}$ bonds with organometallic reagents, such as Shilov chemistry or many $\mathrm{Pd}$-catalyzed $\mathrm{C}-\mathrm{H}$ functionalizations, generally requires harsh conditions or utilizes a directing group approach because of the low acidity and weak coordination capability of aliphatic C-H bonds [174-177]. On the other hand, it has been long recognized that direct functionalization of aliphatic $\mathrm{C}-\mathrm{H}$ bonds can be achieved via radical chemistry [178-180]. A classic example is the radical chlorination of hydrocarbons with $\mathrm{Cl}_{2}$ under photolytic or thermal conditions, which have been used for the industrial synthesis of chloroform and dichloromethane from methane [181]. The power of radical $\mathrm{C}-\mathrm{H}$ activation has been further demonstrated by the recent renaissance of catalytic radical-based methods, especially photoredox catalysis that has provided a variety of new methods for aliphatic $\mathrm{C}-\mathrm{H}$ functionalization reactions [182-184].

In this context, the radical rebound strategy employed by iron-containing oxygenases represents a novel and general paradigm for effecting direct aliphatic $\mathrm{C}-\mathrm{H}$ functionalizations. There are three main features that set this biological approach apart from other radical $\mathrm{C}-\mathrm{H}$ activation methodologies (Fig. 20). First, the $\mathrm{C}-\mathrm{H}$ activation is mediated by first-row metal complexes such as metal-oxo intermediates instead of organic or inorganic radicals commonly seen in radical reactions. The use of metal-based 
Fig. 21 a Detection of the chlorination product in alkane hydroxylation catalyzed by a manganese porphyrin. b Halogenation reactivity of several non-heme iron model compounds (a)

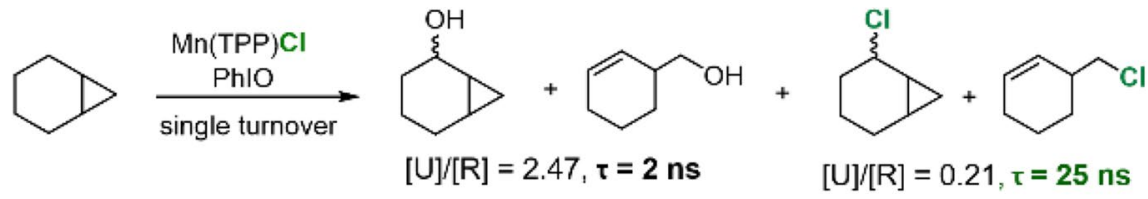

(b) Que, 1993

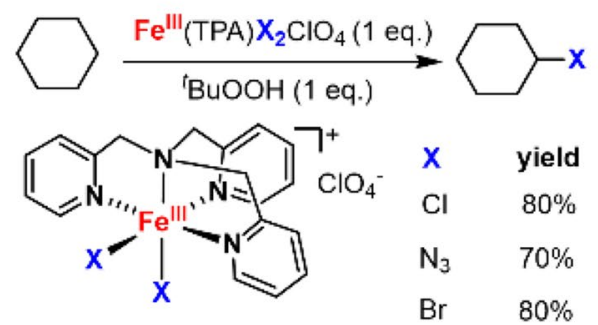

Comba, 2010

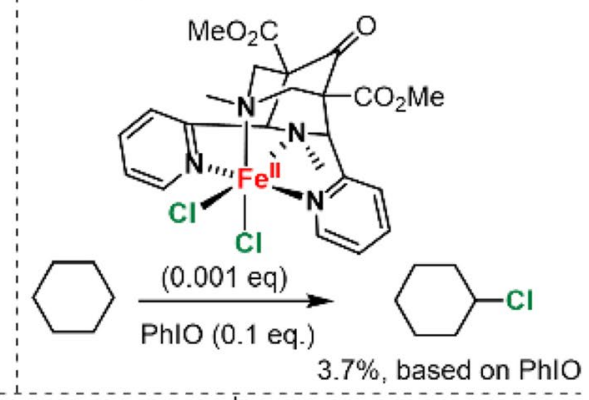

Que, 2016

$\left[\mathrm{Fe}^{\mathrm{IV}}(\mathrm{O})(\mathrm{TQA}) \mathrm{X}\right]^{+}$
Costas, 2014

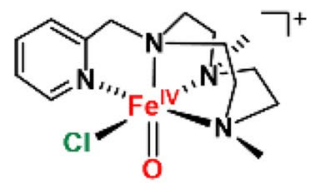

$\left[\mathrm{Fe}^{\mathrm{IV}}(\mathrm{O})(\mathrm{Cl})(\mathrm{Pytacn})\right]^{+}$ hydrogen abstracting intermediates enables the control of regioselectivity of $\mathrm{C}-\mathrm{H}$ activation beyond the innate reactivity of $\mathrm{C}-\mathrm{H}$ bonds. With this approach, stronger primary or secondary $\mathrm{C}-\mathrm{H}$ bonds can be selectively functionalized in the presence of much weaker tertiary $\mathrm{C}-\mathrm{H}$ bonds. Second, in a radical rebound approach, the new bond formation step of carbon-centered radical also proceeds through a metal-based intermediate, allowing for highly stereoselective trapping of the carbon-centered radicals. This feature resembles several photoredox reactions in which a nickel or copper catalyst can trap the alkyl radicals and effect enantioselective $\mathrm{C}-\mathrm{C}$ or $\mathrm{C}-\mathrm{N}$ bond formations. Another feature of the radical rebound approach is the controlled generation of carbon-centered radicals rather than radical chain mechanisms for many organic radical transformations. In biology, this feature is critical as freely diffusing carbon radicals are harmful to the biological system. This characteristic is also desired for organic transformations as it will eliminate unwanted side reactions.

There are many catalytic systems for aliphatic $\mathrm{C}-\mathrm{H}$ hydroxylation reactions based on synthetic models of Fecontaining oxygenases, which have been reviewed extensively $[17,18,185]$. Herein, we will mainly focus on nonoxygenation reactions via the radical rebound mechanism, which has offered solutions to several most challenging reactions in synthetic organic chemistry.
The first hint of such nonoxygenation reactions was obtained during our investigation of synthetic models for P450s. In 1980, we found that manganese porphyrins can effect highly efficient alkane hydroxylations. In this reaction, side chlorination products were also observed, which were determined to derive from the chloride axial ligand on the manganese porphyrin catalyst [55]. The mechanistically diagnostic radical clock norcarane used in that study clearly showed the presence of the radical rearranged chlorination product, 3-chloromethyl-cyclohexene. This chlorination product was formed through a hydrogen abstraction/radical rebound pathway with a radical lifetime of $\sim 25 \mathrm{~ns}$ (Fig. 21a). Subsequent studies by our group and the Hill group showed that a variety of axial ligands, including bromide, iodide, and azide, could undergo this oxidative ligand transfer reaction [186-188]. Meunier and coworkers also found that manganese porphyrin $/ \mathrm{NaOCl}$ system could effect $\mathrm{C}-\mathrm{H}$ chlorination of cyclohexane [189]. In 1993, Que and co-workers demonstrated that such ligand transfer reaction also occurred with non-heme iron complexes [190]. Very recently, several oxoiron(IV) non-heme complexes with a cis-coordinated chloride ligand have been examined because of their resemblance to the halogenation intermediate of iron halogenases (Fig. 21b) [191-193]. Reactivity studies revealed that some of these complexes can effect aliphatic $\mathrm{C}-\mathrm{H}$ chlorination with a ratio of oxygenation to halogenation varying from $\sim 1$ to $\sim 6$. 


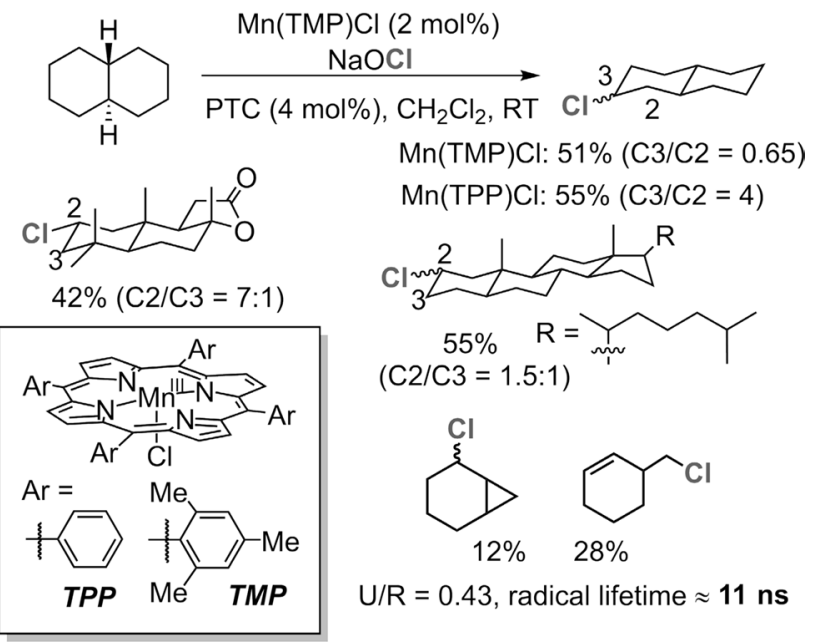

Fig. 22 Aliphatic C-H chlorination catalyzed by manganese porphyrins

A standing challenge for implementing the radical rebound approach for catalytic $\mathrm{C}-\mathrm{H}$ functionalization has been the suppression of the oxygenation products formed via oxygen rebound. The first breakthrough was achieved in 2010, when we discovered an unusual manganese porphyrin-catalyzed aliphatic $\mathrm{C}-\mathrm{H}$ chlorination reaction (Fig. 22) [194]. With sodium hypochlorite as the oxidant and chlorine source, a variety of hydrocarbons were readily chlorinated with only trace amount of oxygenation products. Product selectivities were very much different than those of typical chlorination reactions. The chlorination of trans-decalin, for example, afforded mainly secondary chlorination products $\left(2^{\circ} / 3^{\circ}>9\right)$, which is in drastic contrast to the chlorination of the same substrate with $N$-chlorosuccinimide (NCS) or hypochlorous acid $\left(2 \% 3^{\circ}\right.$ ratio $\sim 0.7$ and 0.3 ). Furthermore, the sterically bulky Mn(TMP) $\mathrm{Cl}$ catalyst yielded chlorination products with a $\mathrm{C} 3 / \mathrm{C} 2$ ratio of 4 , much higher than that of the less sterically hindered $\mathrm{Mn}(\mathrm{TPP}) \mathrm{Cl}(\mathrm{C} 3 / \mathrm{C} 2=0.65)$. These results demonstrated that the regioselectivity of these radical $\mathrm{C}-\mathrm{H}$ chlorination reactions can be regulated by the steric and electronic properties of the catalyst, hints of which were seen in the very early hydroxylation work (Fig. 6) [55, 56]. This catalytic chlorination also showed high stereoselectivities during the chlorine transfer step. For example, $5 \alpha$-cholestane was selectively chlorinated at $\mathrm{C} 2$ and $\mathrm{C} 3$ positions with equatorial to axial ratio of $15: 1$ and 1:2, respectively.

Radical clock studies showed that the reaction followed a radical mechanism with a radical lifetime $\sim 11 \mathrm{ns,} \mathrm{which}$ is much longer than that of the analogous hydroxylation ( $\sim 2 \mathrm{~ns}$ ). No cation rearranged product was observed, which further indicated a radical rebound mechanism.

An intriguing question is what slows down the oxygen rebound and inhibits the oxygenation products in this

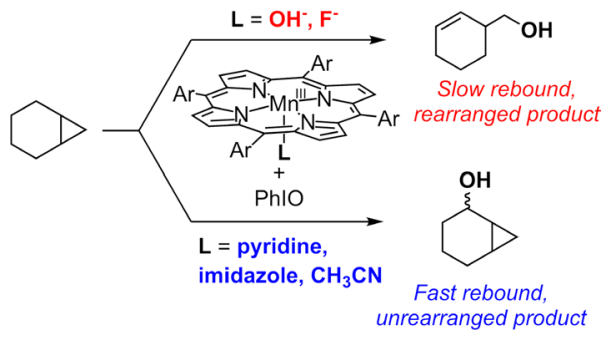

Fig. 23 Effect of axial ligands on the oxygen rebound step

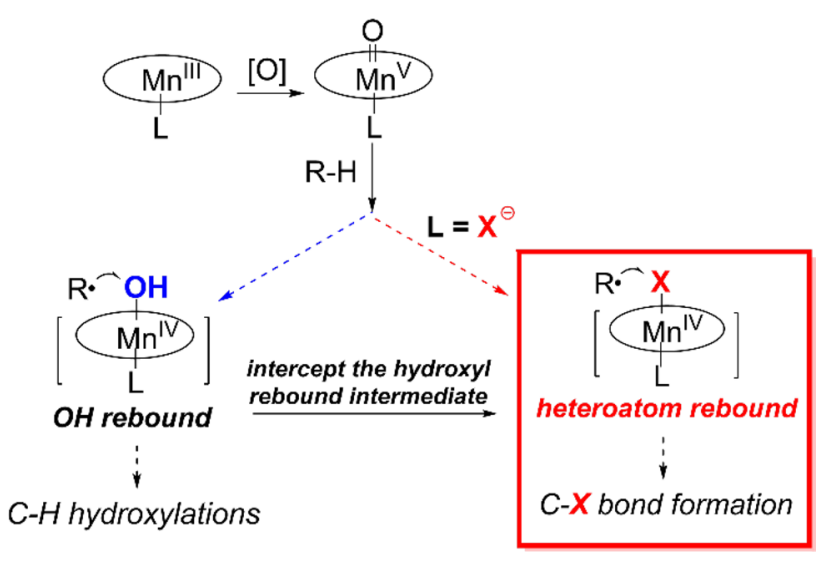

Fig. 24 The concept of heteroatom rebound catalysis (HRC) for developing $\mathrm{C}-\mathrm{H}$ functionalization reactions

chlorination reaction. Later studies showed that the axial ligand played an important role in determining the radical lifetime of the incipient carbon radicals (Fig. 23). The addition of strongly ligating imidazole or pyridine to the chlorination system significantly suppressed chlorination and led to oxygenation products instead [195]. This axial ligand effect was further supported by the radical clock analysis of the Mn-catalyzed hydroxylation reaction in which radical lifetime increased significantly by changing the axial ligand from imidazole or pyridine to anionic $\sigma$-donating ligands hydroxide and fluoride.

This unprecedented axial ligand effect on radical rebound offered a general strategy to develop biomimetic radical $\mathrm{C}-\mathrm{H}$ functionalization reactions that nature had not yet devised via the control of the radical rebound step (Fig. 24). A good demonstration of this approach is the development of an unprecedented aliphatic $\mathrm{C}-\mathrm{H}$ fluorination with fluoride ion developed by our group in 2012 [196]. The rationale of this reaction is that the addition of fluoride ion would suppress oxygen rebound and the incipient radical could be redirected to recombine with a $\mathrm{Mn}^{\mathrm{IV}}-\mathrm{F}$ intermediate in a process that resembles oxygen rebound. Although there are many examples of radical fluorination based on electrophilic fluorination reagents [197-200], radical fluorination with fluoride-derived Mn-F 


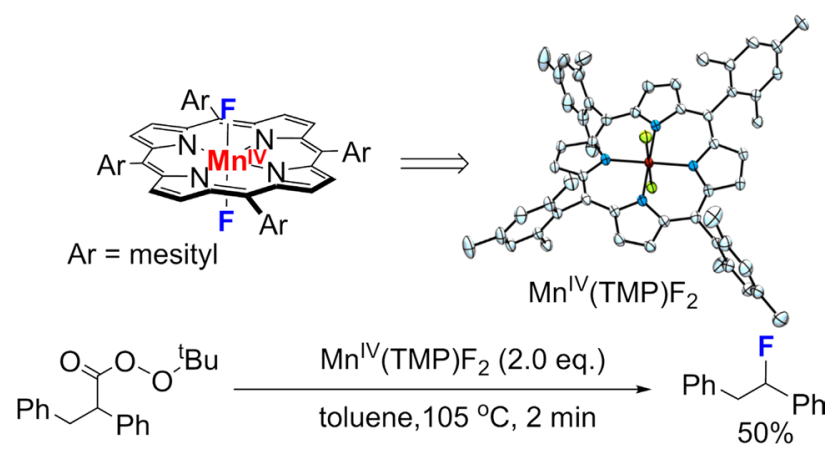

Fig. 25 Trapping of alkyl radicals by trans $-\mathrm{Mn}^{\mathrm{IV}}(\mathrm{TMP}) \mathrm{F}_{2}$ via fluorine atom transfer. X-ray crystal structure of trans $-\mathrm{Mn}^{\mathrm{IV}}(\mathrm{TMP}) \mathrm{F}_{2}$ drawn at $50 \%$ probability of the electron density with following atom colors: F (yellow), Mn (magenta), N (blue), C (cyan) (H atoms are omitted for clarity)

rebound was unprecedented. A significant challenge to developing fluoride-based radical fluorination lies in the high oxidation potential of fluoride ion that typically prevents it from participating in redox chemistry [201-203]. We found that binding of fluoride ion to a manganese(IV) porphyrin activated it toward fluorine atom transfer to the substrate alkyl radical. To probe this idea, a unique transdifluoromanganese(IV) porphyrin complex was synthesized and isolated. Treating this species with radical precursors generated under thermolytic conditions afforded alkyl fluoride products via radical trapping in high yields (Fig. 25).

With this mechanistic insight in hand, we developed the first fluoride-based aliphatic $\mathrm{C}-\mathrm{H}$ fluorination reaction
(Fig. 26a) [196]. Like the manganese porphyrin-catalyzed chlorination, this reaction showed catalyst-controlled regioselectivity with a preference for secondary aliphatic $\mathrm{C}-\mathrm{H}$ bonds in the presence of weaker tertiary $\mathrm{C}-\mathrm{H}$ bonds. High regio- and stereo-selectivity were achieved for a number of complex substrates including the terpenoid sclareolide and a steroid, $5 \alpha$-androstan-17-one. Radical clock studies again showed a radical rebound mechanism with radical lifetimes of $\sim 2$ ns. Highly selective benzylic $\mathrm{C}-\mathrm{H}$ fluorination was achieved by changing the catalyst to manganese salens (Fig. 26b). When using a chiral manganese salen catalyst, a $20 \%$ ee was detected for the fluorination of celestolide. This small but mechanistically revealing enantioselectivity led strong support for the radical rebound to a catalystbound $\mathrm{Mn}-\mathrm{F}$ intermediate. DFT calculations to probe this process predicted a very low energy barrier $(\sim 3 \mathrm{kcal} / \mathrm{mol})$ for such a fluorine rebound process from manganese.

The use of fluoride ion in this $\mathrm{C}-\mathrm{H}$ fluorination reaction allowed us to develop the first ${ }^{18} \mathrm{~F}$ labeling reaction of aliphatic $\mathrm{C}-\mathrm{H}$ bonds using $\left[{ }^{18} \mathrm{~F}\right]$ fluoride, which could have wide applications in positron emission tomography (PET) (Fig. 27) [204]. $\left[{ }^{18} \mathrm{~F}\right]$ fluoride is the preferred ${ }^{18} \mathrm{~F}$ source for molecular labeling with ${ }^{18} \mathrm{~F}$ for PET because of its high specific activity (a measure of ${ }^{18} \mathrm{~F} /{ }^{19} \mathrm{~F}$ ratio in the labeled molecules) [205]. The major challenge of this labeling reaction is the short half-life of the ${ }^{18} \mathrm{~F}$ radionuclide ( $110 \mathrm{~min})$ and its minuscule quantities (pmol-nmol) under typical radiochemical process conditions [206, 207]. We found that manganese salen catalysts with a labile tosylate ligand could efficiently trap pmol of ${ }^{18} \mathrm{~F}$ in the solution with over $90 \%$ efficiency. With this approach,
Fig. 26 a Aliphatic C-H fluorination catalyzed by manganese porphyrins. b Benzylic C-H fluorination catalyzed by magnanese salens (a)
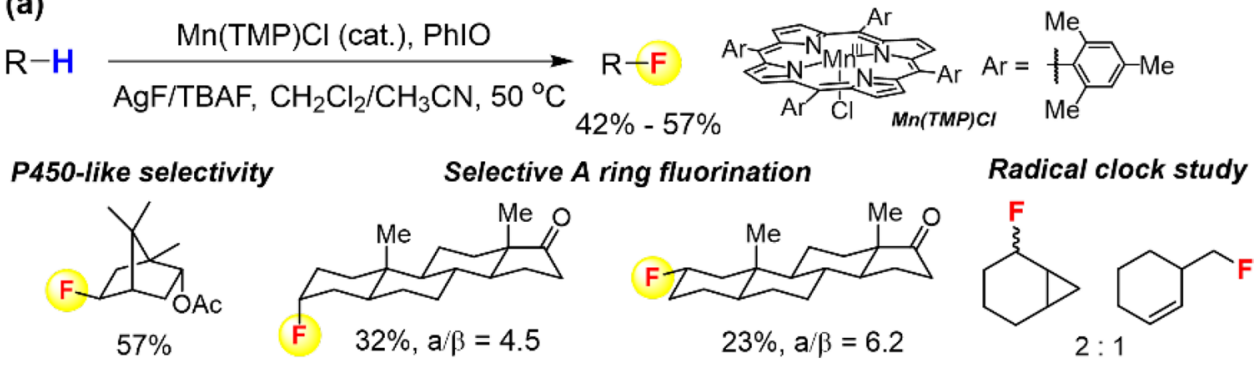

(b)

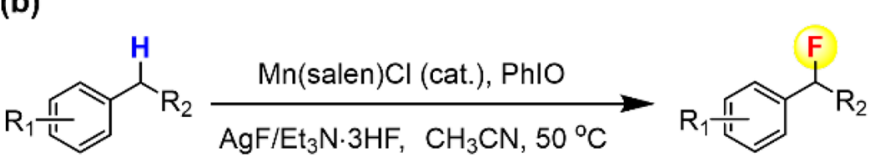

$47 \%-70 \%$

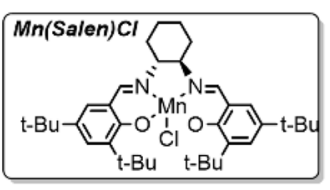

anti-inflammatory drug

perfume component
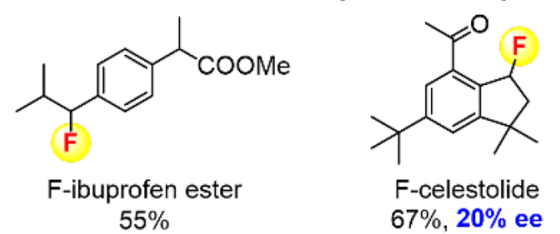

non-natural amino acid
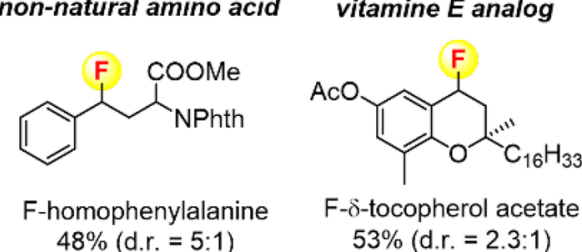


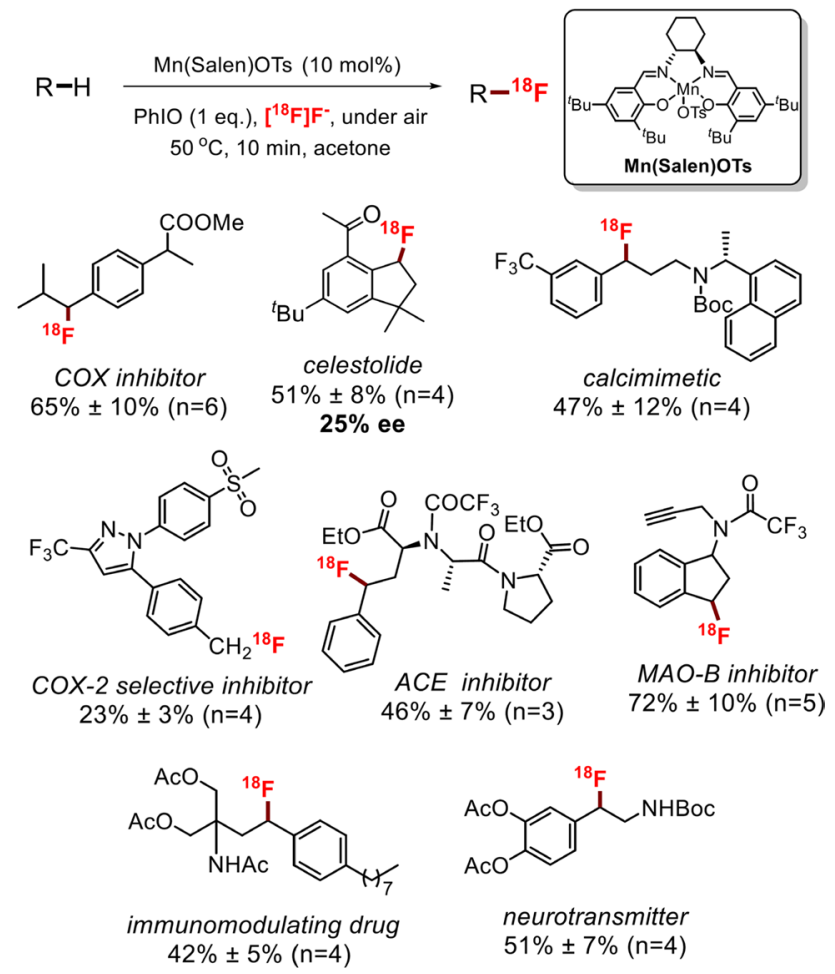

Fig. 27 Aliphatic $\mathrm{C}-\mathrm{H}{ }^{18} \mathrm{~F}$ labeling mediated by manganese salen catalysts

our labeling method effects efficient $\mathrm{C}-\mathrm{H}{ }^{18} \mathrm{~F}$ labeling of a variety of substrates including nine complex drug molecules or drug analogs within 10 min with very practical radiochemical conversions (conversion of ${ }^{18} \mathrm{~F}$ into the target molecule) up to $70 \%$. Mechanistic studies showed that this reaction also proceeded through an $\mathrm{H}$-abstraction/ fluorine rebound mechanism as a $25 \%$ ee was observed for the ${ }^{18} \mathrm{~F}$ labeling of celestolide with chiral manganese salen catalyst. The success of this ${ }^{18} \mathrm{~F}$ labeling reaction provided critical insight to the fluorine rebound step. It is worth noting that in ${ }^{18} \mathrm{~F}$ reactions, all other reactants, including the manganese 'catalyst', are in vast excess because of the tiny quantity of ${ }^{18} \mathrm{~F}$ fluoride (pmol). Therefore, the concentration of the $\mathrm{Mn}^{\mathrm{IV}}-{ }^{18} \mathrm{~F}$ intermediate would be much lower that of $\mathrm{Mn}^{\mathrm{IV}}-\mathrm{OH}$ intermediate. However, the observed high ${ }^{18} \mathrm{~F}$ conversion into target molecule suggests that the radical rebound to $\mathrm{Mn}^{\mathrm{IV}}-{ }^{18} \mathrm{~F}$ must be highly selective in capturing incipient alkyl radicals.

The radical rebound approach is not only restricted to carbon-halogen bond formation reactions. Azide is another important functionality that has versatile applications in organic synthesis and biorthogonal chemistry [208, 209]. Azide transfer from metal-azide complexes to alkyl radicals is well known [210, 211]. We developed a manganese-catalyzed late-stage aliphatic $\mathrm{C}-\mathrm{H}$ azidation reaction following the chemical logic of $\mathrm{H}$ abstraction/azide rebound (Fig. 28)

$$
\text { R-H } \underset{\mathrm{Mn}(\mathrm{TMP}) \mathrm{Cl} \text { or } \mathrm{Mn} \text { (salen)Cl}}{\stackrel{\mathrm{NaN}}{\mathrm{Naq} \text { (a), } \mathrm{PhlO}}} \mathrm{R}-\mathrm{N}_{3}
$$

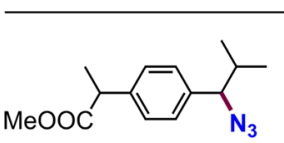

$\mathbf{N}_{3}$-ibuprofen methyl ester $67 \%$

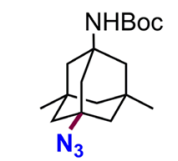

$\mathrm{N}_{3}$-NHBoc-Memantine $47 \%$<smiles>COc1ccc(C(N)c2nccc3cc([N+]#N)ncc23)cc1OC</smiles>

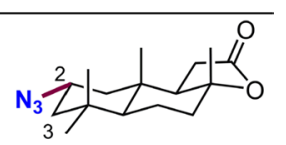

$\mathbf{N}_{3}$-sclareolide $57 \%(\alpha / \beta=7.5)$ $60 \%$
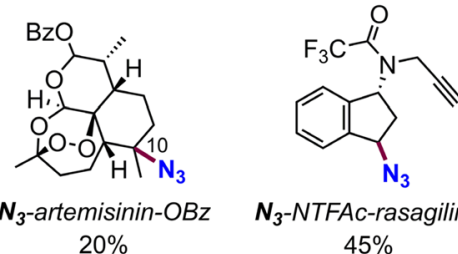

$\mathbf{N}_{3}$-NTFAc-rasagiline $45 \%$

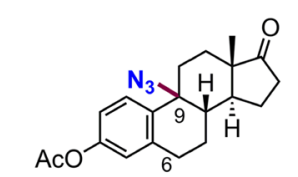

$\mathrm{N}_{3}$-NHBoc-Memantine $38 \%$ (+ $18 \%$ diazidation)

Fig. 28 Manganese-catalyzed late-stage aliphatic $\mathrm{C}-\mathrm{H}$ azidation

[212]. Radical clock studies showed that the radical lifetime of this reaction was around $30 \mathrm{~ns}$, significantly longer than what was observed for chlorination and fluorination. The azidation of celestolide with a chiral manganese salen catalyst afforded product in $70 \%$ ee, which is much higher than that of fluorination. DFT calculations showed that the azide transfer from $\mathrm{Mn}^{\mathrm{IV}}-\mathrm{N}_{3}$ to an alkyl radical adopted a bent geometry for all reaction pathways because of the linear shape of azide, whereas the lowest-energy pathway of fluorine transfer showed a linear $\sigma$-geometry, pushing alkyl radicals away from the steric environment of the ligand, leading to low enantioselectivity (Fig. 29).

This series of unprecedented radical $\mathrm{C}-\mathrm{H}$ functionalization reactions share common features and mechanistic foundations. They are all initiated by hydrogen abstraction via oxoMn ${ }^{\mathrm{V}}$ intermediates, which give rise to the tunable regioselectivity that can surpass the restriction of innate reactivity of aliphatic $\mathrm{C}-\mathrm{H}$ bonds. The oxygen rebound in these reactions are all suppressed due to the presence of strong anionic $\sigma$-donating ligands. Although more studies are needed to further elucidate the nature of non-oxygen rebounding intermediate, radical clock studies with norcarane showed long radical lifetimes $(\sim 2 \mathrm{~ns}$ for fluorination, $\sim 10 \mathrm{~ns}$ for chlorination, and $\sim 30 \mathrm{~ns}$ for azidation). The long radical lifetime seems to be crucial for the success of non-oxygenation reactivity, as changing the catalyst to more electron-withdrawing manganese porphyrins [such as $\mathrm{Mn}$ (TPFPP)Cl or $\mathrm{Mn}(\mathrm{TDCPP}) \mathrm{Cl}]$ or iron porphyrins suppresses the non-oxygenation reactivity and yields mainly 

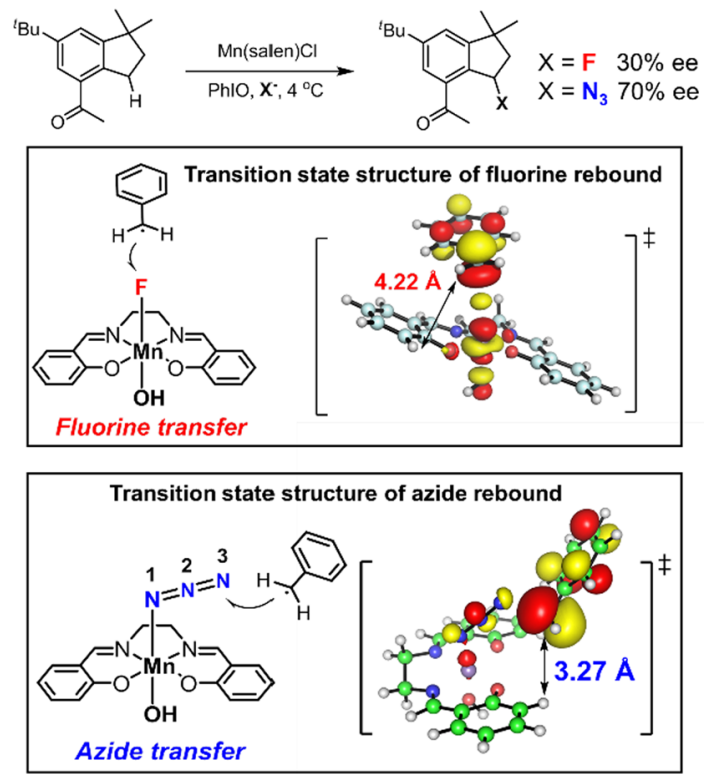

Fig. 29 Comparison of the enantioselectivity between Mn-catalyzed $\mathrm{C}-\mathrm{H}$ azidation and fluorination

oxygenation products. The stereoselectivity and the enantioselectivity of the reactions can be controlled by the catalyst through metal-mediated radical rebound. Such control of stereoselectivity is difficult to achieve with simple organic or inorganic radical trapping reagents.

The above examples show just a glimpse of the potential applications of radical rebound strategy in developing new radical organic transformations. Both the $\mathrm{C}-\mathrm{H}$ activation and radical recombination approaches adopted by iron-containing oxygenases could likely be combined with current catalytic radical methodologies to afford new radical transformations. In one scenario, one can imagine that the carbon-centered radicals can be generated by the $\mathrm{C}-\mathrm{H}$ activation via metal-oxo or similar metal-based hydrogen abstracting intermediates and subsequently be redirected to carbon-carbon or carbon-heteroatom bond formation via transition-metal mediated transformations. Such reactions would harness the controllable selectivity of metal-based hydrogen-abstracting intermediate in $\mathrm{C}-\mathrm{H}$ activation step, which is hard to achieve with simple organic or inorganic radicals. In another case, carbon radicals could be generated with other radical initiation methods such as photoredox reactions, electrolysis, or other single-electron transfer (SET) processes, and later be captured by metal complexes [213-215]. The works of Kochi in 1970s have provided early examples of this type of reactions. He showed that various metal halide or pseudohalide complexes [i.e. $\mathrm{CuBr}_{2}, \mathrm{~Pb}(\mathrm{OAc})_{4}$, etc.] were able to trap alkyl radicals generated by photolysis or thermolysis to afford halogenation or pseudohalogenation products $[210,211,216]$. Very

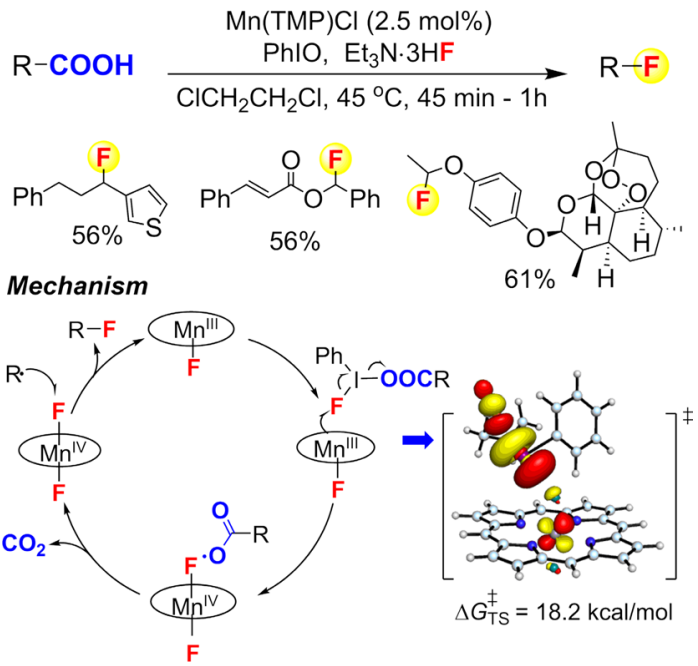

Fig. 30 Mn-catalyzed decarboxylative fluorination

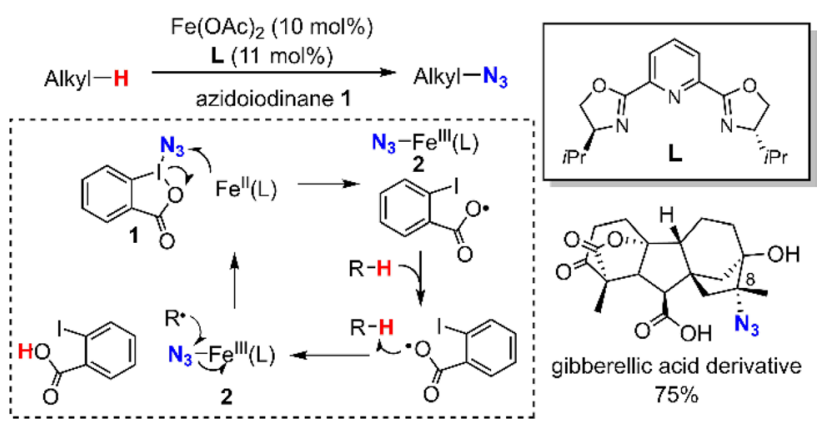

Fig. 31 Fe-catalyzed aliphatic $\mathrm{C}-\mathrm{H}$ azidation

recently, this area of research has seen dramatic progress mainly due to the development of photoredox catalysis. New methodologies have been developed for the construction of various carbon-carbon and carbon-heteroatom bonds via trapping the intermediate carbon radicals with transition-metal complexes especially nickel and copper [214, 217-223].

Studies of Fe-containing oxygenases and related model compounds discussed above indicate that manganese and iron complexes also hold great premise for trapping the substrate radical intermediate, especially for the formation of carbon-halogen and carbon-pseudohalogen bonds. Following this design strategy, we recently developed the first decarboxylative fluorination reaction with fluoride ion (Fig. 30) [224]. In this reaction, the radical is generated via manganese-mediated oxidative decarboxylation. The generated radical is subsequently trapped by the $\mathrm{Mn}^{\mathrm{IV}}-\mathrm{F}$ intermediate to afford fluorination product. Another compelling example was the aliphatic $\mathrm{C}-\mathrm{H}$ azidation reaction reported by Hartwig and co-workers in 2015 [225, 226]. Mechanistic studies supported a reaction mechanism 
shown in Fig. 31. An initial one-electron oxidation between azidoiodinane $\mathbf{1}$ and iron(II) afforded a bezyloxyl radical and an azidoferric intermediate 2 . Benzyloxyl will abstract a hydrogen from the substrate and the substrate radical will be subsequently trapped by azidoferric intermediate $\mathbf{2}$ to afford azidation product. The reaction can functionalize complex molecules with multiple aliphatic $\mathrm{C}-\mathrm{H}$ bonds with high regio- and stereo-selectivity. For example, a gibberellic acid derivative can be readily azidated giving a single diasterisomer with $75 \%$ yield. It is worth noting that in the absence of iron catalyst, azidoiodinane $\mathbf{1}$ can also azidate hydrocarbons with catalytic amount of radical initiators such as benzoyl peroxide with much lower stereoselectivity. This result highlighted the benefit of using metal complexes as radical trapping agents.

In addition to non-oxygen atom rebound, other reaction pathways adopted by iron-containing oxygenases are also highly valuable to the organic synthesis, such as alkane desaturation and radical cyclizations. There are relatively few studies on these reactions. The elucidation of their biochemical mechanisms and the design of synthetic model compounds to mimic the reactivities would definitely lead to new inventions in organic synthesis.

\section{Concluding remarks}

It has been 40 years since our initial work on the radical rebound mechanism. The goals all along were to compare, contrast, and unify biocatalytic mechanisms with biomimetic systems. Iron-containing oxygenases continue to comprise a highly active research area with numerous new enzymes and numerous new reaction discoveries being made every year. What is fascinating about these enzymes is the diverse range of transformations they can catalyze. What is even more intriguing is the common mechanistic foundation underlying these various reactions: activation of oxygen to form high-valent iron-oxygen containing intermediates; abstraction of $\mathrm{C}-\mathrm{H}$ bonds to yield radical intermediate; and the participation of the carbon-centered radicals in different reaction pathways giving rise to the diverse reactivities observed for iron-containing oxygenases. The study of the fundamental reactivities of these enzymes has inspired critical breakthroughs in synthetic organic chemistry, from early development of new molecular catalysts for alkane hydroxylations to the most recent progress in $\mathrm{C}-\mathrm{H}$ halogenation reactions. We can expect iron-containing enzymes to continue powering the discoveries of new organic transformations because of the continuous discoveries and understanding of new reactivities of these enzymes as well as the recent renaissance of radical chemistry in organic synthesis.
Acknowledgements Deepest thanks are due to all the co-workers from the Groves laboratories, both at the University of Michigan, for the earliest work, and Princeton University. JTG thanks Ronald Breslow for stimulating an early interest in biomimetic chemistry, Cheves Walling for deep insights regarding kinetics and mechanism and Jud Coon and Vince Massey for an introduction to oxygenases. We thank those involved in the metalloporphyrin and P450/APO studies referred to in this review for their invaluable intellectual and experimental contributions. We are especially indebted to Dr. Wei Liu for his contributions to the discovery and development of the Mn-F chemistry. Mn-porphyrin research was supported by the U.S. National Science Foundation Awards CHE-1148597 and CHE-1464578 and the Center for Catalytic Hydrocarbon Functionalization, an Energy Frontier Research Center, U.S. Department of Energy, Office of Science, Basic Energy Sciences, under Award No. DESC0001298. P450 and APO enzymology was supported by the National Institutes of Health (2R37 GM036298). XYH thanks Merck, Inc. for fellowship support.

Open Access This article is distributed under the terms of the Creative Commons Attribution 4.0 International License (http://creativecommons.org/licenses/by/4.0/), which permits unrestricted use, distribution, and reproduction in any medium, provided you give appropriate credit to the original author(s) and the source, provide a link to the Creative Commons license, and indicate if changes were made.

\section{References}

1. Groves JT (2003) Proc Natl Acad Sci USA 100:3569-3574

2. Groves JT (2006) J Inorg Biochem 100:434-447

3. Bobrowski M, Liwo A, Oldziej S, Jeziorek D, Ossowski T (2000) J Am Chem Soc 122:8112-8119

4. Oshea KE, Foote CS (1988) J Am Chem Soc 110:7167-7170

5. Kovaleva EG, Lipscomb JD (2008) Nat Chem Biol 4:186-193

6. Pau MYM, Lipscomb JD, Solomon E (2007) Proc Natl Acad Sci U S A 104:18355-18362

7. Visitsatthawong S, Chenprakhon P, Chaiyen P, Surawatanawong P (2015) J Am Chem Soc 137:9363-9374

8. Chaiyen P, Fraaije MW, Mattevi A (2012) Trends Biochem Sci 37:373-380

9. McDonald CA, Fagan RL, Collard F, Monnier VM, Palfey BA (2011) J Am Chem Soc 133:16809-16811

10. Costas M, Mehn MP, Jensen MP, Que L (2004) Chem Rev 104:939-986

11. Solomon EI, Baldwin MJ, Lowery MD (1992) Chem Rev 92:521-542

12. Solomon EI, Sundaram UM, Machonkin TE (1996) Chem Rev 96:2563-2605

13. Lewis EA, Tolman WB (2004) Chem Rev 104:1047-1076

14. Stubbe J, van der Donk WA (1998) Chem Rev 98:705-762

15. Mirica LM, Ottenwaelder X, Stack TDP (2004) Chem Rev 104:1013-1045

16. Tolman WB (1997) Acc Chem Res 30:227-237

17. Che CM, Lo VKY, Zhou CY, Huang JS (2011) Chem Soc Rev 40:1950-1975

18. Bauer I, Knoelker HJ (2015) Chem Rev 115:3170-3387

19. Cernak T, Dykstra KD, Tyagarajan S, Vachal P, Krska SW (2016) Chem Soc Rev 45:546-576

20. Hartwig JF, Larsen MA (2016) ACS Cent Sci 2:281-292

21. Que L, Tolman WB (2008) Nature 455:333-340

22. Ortiz de Montellano PR (ed) (2005) Cytochrome p450: structure, mechanism, and biochemistry. Kluwer Academic/Plenum Publishers, New York 
23. Ortiz de Montellano PR (ed) (2015) Cytochrome p450: structure, mechanism, and biochemistry, 4th edn. Springer International Publishing, Switzerland

24. Groves JT (1985) J Chem Educ 62:928-931

25. Groves JT (2005) In: Ortiz de Montellano PR (ed) Cytochrome p450: structure, mechanism, and biochemistry, 3rd edn. Kluwer Academic/Plenum Publishers, New York, pp 1-34

26. Glieder A, Farinas ET, Arnold FH (2002) Nat Biotechnol 20:1135-1139

27. Lewis JC, Coelho PS, Arnold FH (2011) Chem Soc Rev 40:2003-2021

28. Groves JT, Van Der Puy M (1976) J Am Chem Soc 98:5290-5297

29. Groves JT, McClusky GA, White RE, Coon MJ (1978) Biochem Biophys Res Commun 81:154-160

30. Groves JT, McClusky GA (1976) J Am Chem Soc 98:859-861

31. Meunier B, de Visser SP, Shaik S (2004) Chem Rev 104:3947-3980

32. Ortiz de Montellano PR (2010) Chem Rev 110:932-948

33. Fenton HJH (1894) J Chem Soc Trans 65:899-910

34. Walling C (1975) Acc Chem Res 8:125-131

35. F. Haber and J. Weiss (1934) Proc R Soc London, A 147:332-351

36. Bray WC, Gorin MH (1932) J Am Chem Soc 54:2124-2125

37. Merz JH, Waters WA (1949) J Chem Soc 15:2427-2433

38. Cahill AE, Taube H (1952) J Am Chem Soc 74:2312-2318

39. Conocchi TJ, Hamilton EJ, Sutin N (1965) J Am Chem Soc 87:926-927

40. Wink DA, Nims RW, Saavedra JE, Utermahlen WE, Ford PC (1994) Proc Natl Acad Sci USA 91:6604-6608

41. Pestovsky O, Bakac A (2006) Inorg Chem 45:814-820

42. Bataineh H, Pestovsky O, Bakac A (2012) Chem Sci 3:1594-1599

43. Bataineh H, Pestovsky O, Bakac A (2015) ACS Catal 5:1629-1637

44. Groves JT, Subramanian DV (1984) J Am Chem Soc 106:2177-2181

45. Davydov R, Makris TM, Kofman V, Werst DE, Sligar SG, Hoffman BM (2001) J Am Chem Soc 123:1403-1415

46. Palcic MM, Rutter R, Araiso T, Hager LP, Dunford HB (1980) Biochem Biophys Res Commun 94:1123-1127

47. Egawa T, Proshlyakov DA, Miki H, Makino R, Ogura T, Kitagawa T, Ishimura Y (2001) J Biol Inorg Chem 6:46-54

48. Rutter R, Hager LP, Dhonau H, Hendrich M, Valentine M, Debrunner P (1984) Biochemistry 23:6809-6816

49. Hoffman BM (2003) Proc Natl Acad Sci USA 100:3575-3578

50. Stone KL, Behan RK, Green MT (2005) Proc Natl Acad Sci USA 102:16563-16565

51. Dolphin D, Forman A, Borg DC, Fajer J, Felton RH (1971) Proc Natl Acad Sci USA 68:614-618

52. van Rantwijk F, Sheldon RA (2000) Curr Opin Biotechnol 11:554-564

53. Boso B, Lang G, McMurry TJ, Groves JT (1983) J Chem Phys 79:1122-1126

54. Penner-Hahn JE, McMurry TJ, Renner M, Latosgrazynsky L, Eble KS, Davis IM, Balch AL, Groves JT, Dawson JH, Hodgson KO (1983) J Biol Chem 258:2761-2764

55. Groves JT, Kruper WJ, Haushalter RC (1980) J Am Chem Soc 102:6375-6377

56. Groves JT, Nemo TE (1983) J Am Chem Soc 105:6243-6248

57. Groves JT, Takahashi T, Butler WM (1983) Inorg Chem 22:884-887

58. Groves JT, Haushalter RC (1981) J Chem Soc Chem Commun $1165-1166$

59. Leung WH, Che CM (1989) J Am Chem Soc 111:8812-8818

60. Jin N, Groves JT (1999) J Am Chem Soc 121:2923-2924
61. Jin N, Ibrahim M, Spiro TG, Groves JT (2007) J Am Chem Soc 129:12416-12417

62. Groves JT, Lee JB, Marla SS (1997) J Am Chem Soc 119:6269-6273

63. Jin N, Bourassa JL, Tizio SC, Groves JT (2000) Angew Chem Int Ed 39:3849-3851

64. Bell SR, Groves JT (2009) J Am Chem Soc 131:9640-9641

65. Wang Q, Sheng X, Horner JH, Newcomb M (2009) J Am Chem Soc 131:10629-10636

66. Chandrasena REP, Vatsis KP, Coon MJ, Hollenberg PF, Newcomb M (2004) J Am Chem Soc 126:115-126

67. Newcomb M, Aebisher D, Shen RN, Chandrasena REP, Hollenberg PF, Coon MJ (2003) J Am Chem Soc 125:6064-6065

68. Rittle J, Green MT (2010) Science 330:933-937

69. Wang X, Peter S, Ullrich R, Hofrichter M, Groves JT (2013) Angew Chem Int Ed 52:9238-9241

70. Wang XS, Peter S, Kinne M, Hofrichter M, Groves JT (2012) J Am Chem Soc 134:12897-12900

71. Strittmatter E, Liers C, Ullrich R, Wachter S, Hofrichter M, Plattner DA, Piontek K (2013) J Biol Chem 288:4095-4102

72. Boaz NC, Bell SR, Groves JT (2015) J Am Chem Soc 137:2875-2885

73. Bordwell FG (1988) Acc Chem Res 21:456-463

74. Janousek BK, Reed KJ, Brauman JI (1980) J Am Chem Soc 102:3125-3129

75. Mayer JM (2011) Acc Chem Res 44:36-46

76. Warren JJ, Tronic TA, Mayer JM (2010) Chem Rev 110:6961-7001

77. Mayer JM (2004) Annu Rev Phys Chem 55:363-390

78. Groves JT (2014) Nat Chem 6:89-91

79. Green MT (2009) Curr Opin Chem Biol 13:84-88

80. Behan RK, Green MT (2006) J Inorg Biochem 100:448-459

81. Green MT, Dawson JH, Gray HB (2004) Science 304:1653-1656

82. Yosca TH, Rittle J, Krest CM, Onderko EL, Silakov A, Calixto JC, Behan RK, Green MT (2013) Science 342:825-829

83. Wang X, Ullrich R, Hofrichter M, Groves JT (2015) Proc Natl Acad Sci USA 112:3686-3691

84. Bruijnincx PCA, van Koten G, Gebbink RJMK (2008) Chem Soc Rev 37:2716-2744

85. Elkins JM, Ryle MJ, Clifton IJ, Dunning Hotopp JC, Lloyd JS, Burzlaff NI, Baldwin JE, Hausinger RP, Roach PL (2002) Biochemistry 41:5185-5192

86. O'Brien JR, Schuller DJ, Yang VS, Dillard BD, Lanzilotta WN (2003) Biochemistry 42:5547-5554

87. Price JC, Barr EW, Tirupati B, Bollinger JM, Krebs C (2003) Biochemistry 42:7497-7508

88. Sinnecker S, Svensen N, Barr EW, Ye S, Bollinger JM, Neese F, Krebs C (2007) J Am Chem Soc 129:6168-6179

89. Baik MH, Newcomb M, Friesner RA, Lippard SJ (2003) Chem Rev 103:2385-2419

90. Brazeau BJ, Austin RN, Tarr C, Groves JT, Lipscomb JD (2001) J Am Chem Soc 123:11831-11837

91. Banerjee R, Proshlyakov Y, Lipscomb JD, Proshlyakov DA (2015) Nature 518:431-434

92. Shu L, Nesheim JC, Kauffmann K, Münck E, Lipscomb JD, Que L (1997) Science 275:515-518

93. Lee SK, Fox BG, Froland WA, Lipscomb JD, Munck E (1993) J Am Chem Soc 115:6450-6451

94. Wallar BJ, Lipscomb JD (1996) Chem Rev 96:2625-2657

95. Griller D, Ingold KU (1980) Acc Chem Res 13:317-323

96. Ortiz de Montellano PR, Stearns RA (1987) J Am Chem Soc 109:3415-3420

97. Bowry VW, Ingold KU (1991) J Am Chem Soc 113:5699-5707

98. Atkinson JK, Ingold KU (1993) Biochemistry 32:9209-9214 
99. Rozhkova-Novosad EA, Chae JC, Zylstra GJ, Bertrand EM, Alexander-Ozinskas M, Deng DY, Moe LA, van Beilen JB, Danahy M, Groves JT, Austin RN (2007) Chem Biol 14:165-172

100. Auclair K, Hu ZB, Little DM, Ortiz de Montellano PR, Groves JT (2002) J Am Chem Soc 124:6020-6027

101. Newcomb M, Shen R, Choi SY, Toy PH, Hollenberg PF, Vaz ADN, Coon MJ (2000) J Am Chem Soc 122:2677-2686

102. Jin Y, Lipscomb JD (1999) Biochemistry 38:6178-6186

103. Jin Y, Lipscomb JD (2000) BBA Protein Struct M 1543:47-59

104. Austin RN, Buzzi K, Kim E, Zylstra GJ, Groves JT (2003) J Biol Inorg Chem 8:733-740

105. Moe LA, Hu ZB, Deng DY, Austin RN, Groves JT, Fox BG (2004) Biochemistry 43:15688-15701

106. Austin RN, Chang HK, Zylstra GJ, Groves JT (2000) J Am Chem Soc 122:11747-11748

107. Austin RN, Luddy K, Erickson K, Pender-Cudlip M, Bertrand E, Deng D, Buzdygon RS, van Beilen JB, Groves JT (2008) Angew Chem Int Ed 47:5232-5234

108. Cooper HLR, Mishra G, Huang XY, Pender-Cudlip M, Austin RN, Shanklin J, Groves JT (2012) J Am Chem Soc 134:20365-20375

109. Chakrabarty S, Austin RN, Deng DY, Groves JT, Lipscomb JD (2007) J Am Chem Soc 129:3514-3515

110. Cooper HLR, Groves JT (2011) Arch Biochem Biophys 507:111-118

111. Ogliaro F, de Visser SP, Groves JT, Shaik S (2001) Angew Chem Int Ed 40:2874-2878

112. De Angelis F, Jin N, Car R, Groves JT (2006) Inorg Chem 45:4268-4276

113. Hull JF, Balcells D, Sauer ELO, Raynaud C, Brudvig GW, Crabtree RH, Eisenstein O (2010) J Am Chem Soc 132:7605-7616

114. Balcells D, Raynaud C, Crabtree RH, Eisenstein O (2008) Chem Commun 744-746

115. Shaik S, Kumar D, de Visser SP, Altun A, Thiel W (2005) Chem Rev 105:2279-2328

116. Shaik S, Cohen S, de Visser SP, Sharma PK, Kumar D, Kozuch S, Ogliaro F, Danovich D (2004) Eur J Inorg Chem 207-226

117. Filatov M, Harris N, Shaik S (1999) Angew Chem Int Ed 38:3510-3512

118. Shaik S, de Visser SP, Ogliaro F, Schwarz H, Schroder D (2002) Curr Opin Chem Biol 6:556-567

119. Geng CY, Ye SF, Neese F (2010) Angew Chem Int Ed 49:5717-5720

120. Ogliaro F, Harris N, Cohen S, Filatov M, de Visser SP, Shaik S (2000) J Am Chem Soc 122:8977-8989

121. Hohenberger J, Ray K, Meyer K (2012) Nat Commun 3:720

122. Cho KB, Hirao H, Shaik S, Nam W (2016) Chem Soc Rev 45:1197-1210

123. Noyes RM (1961) Prog React Kinet Mech 1:129-160

124. Yoder LM, Cole AG, Walker LA, Sension RJ (2001) J Phys Chem B 105:12180-12188

125. Sension RJ, Harris DA, Stickrath A, Cole AG, Fox CC, Marsh ENG (2005) J Phys Chem B 109:18146-18152

126. Stickrath AB, Carroll EC, Dai XC, Harris DA, Rury A, Smith B, Tang KC, Wert J, Sension RJ (2009) J Phys Chem A 113:8513-8522

127. Groves JT, Nemo TE, Myers RS (1979) J Am Chem Soc 101:1032-1033

128. Su J, Groves JT (2009) J Am Chem Soc 131:12979-12988

129. Su J, Groves JT (2010) Inorg Chem 49:6317-6329

130. Koebke KJ, Pauly DJ, Lerner L, Liu X, Pacheco AA (2013) Inorg Chem 52:7623-7632

131. Cho KB, Shaik S, Nam W (2012) J Phys Chem Lett 3:2851-2856
132. Cho KB, Wu X, Lee YM, Kwon YH, Shaik S, Nam W (2012) J Am Chem Soc 134:20222-20225

133. Cho K-B, Kim EJ, Seo MS, Shaik S, Nam W (2012) Chem Eur J 18:10444-10453

134. Cho K-B, Shaik S, Nam W (2012) J Phys Chem Lett 3:2851-2856

135. Rude MA, Baron TS, Brubaker S, Alibhai M, Del Cardayre SB, Schirmer A (2011) Appl Environ Microbiol 77:1718-1727

136. Wang J-B, Lonsdale R, Reetz MT (2016) Chem Commun 52:8131-8133

137. Hsieh CH, Makris TM (2016) Biochem Biophys Res Commun 476:462-466

138. Grant JL, Hsieh CH, Makris TM (2015) J Am Chem Soc 137:4940-4943

139. Grant JL, Mitchell ME, Makris TM (2016) Proc Natl Acad Sci USA 113:10049-10054

140. Duan L, Jogl G, Cane DE (2016) J Am Chem Soc 138:12678-12689

141. Faponle AS, Quesne MG, de Visser SP (2016) Chem Eur J 22:5478-5483

142. Davydov R, Strushkevich N, Smil D, Yantsevich A, Gilep A, Usanov S, Hoffman BM (2015) Biochemistry 54:7089-7097

143. Yoshimoto FK, Guengerich FP (2014) J Am Chem Soc 136:15016-15025

144. Baldwin JE, Bradley M (1990) Chem Rev 90:1079-1088

145. Tamanaha E, Zhang B, Guo Y, Chang WC, Barr EW, Xing G, St. Clair J, Ye S, Neese F, Bollinger JM, Krebs C (2016) J Am Chem Soc 138:8862-8874

146. Baldwin JE, Adlington RM, Domaynehayman BP, Knight G, Ting HH (1987) J Chem Soc Chem Commun 1661-1663

147. Lundberg M, Siegbahn PEM, Morokuma K (2008) Biochemistry 47:1031-1042

148. Lundberg M, Kawatsu T, Vreven T, Frisch MJ, Morokuma K (2009) J Chem Theory Comput 5:222-234

149. Kawatsu T, Lundberg M, Morokuma K (2011) J Chem Theory Comput 7:390-401

150. Vaillancourt FH, Yin J, Walsh CT (2005) Proc Natl Acad Sci USA 102:10111-10116

151. Blasiak LC, Vaillancourt FH, Walsh CT, Drennan CL (2006) Nature 440:368-371

152. Matthews ML, Krest CM, Barr EW, Vaillancourt FH, Walsh CT, Green MT, Krebs C, Bollinger JM Jr (2009) Biochemistry 48:4331-4343

153. Matthews ML, Neumann CS, Miles LA, Grove TL, Booker SJ, Krebs C, Walsh CT, Bollinger JM (2009) Proc Natl Acad Sci USA 106:17723-17728

154. Wong C, Fujimori DG, Walsh CT, Drennan CL (2009) J Am Chem Soc 131:4872-4879

155. Wong SD, Srnec M, Matthews ML, Liu LV, Kwak Y, Park K, Bell CB III, Alp EE, Zhao J, Yoda Y, Kitao S, Seto M, Krebs C, Bollinger JM Jr, Solomon EI (2013) Nature 499:320-323

156. Martinie RJ, Livada J, Chang WC, Green MT, Krebs C, Bollinger JM, Silakov A (2015) J Am Chem Soc 137:6912-6919

157. Kulik HJ, Blasiak LC, Marzari N, Drennan CL (2009) J Am Chem Soc 131:14426-14433

158. Kulik HJ, Drennan CL (2013) J Biol Chem 288:11233-11241

159. Hillwig ML, Zhu Q, Ittiamornkul K, Liu X (2016) Angew Chem Int Ed 55:5780-5784

160. Mitchell AJ, Zhu Q, Maggiolo AO, Ananth NR, Hillwig ML, Liu X, Boal AK (2016) Nat Chem Biol 12:636-640

161. Hillwig ML, Liu XY (2014) Nat Chem Biol 10:921-923

162. Matthews ML, Chang WC, Layne AP, Miles LA, Krebs C, Bollinger JM (2014) Nat Chem Biol 10:209-215

163. Cooke HA, Peck SC, Evans BS, van der Donk WA (2012) J Am Chem Soc 134:15660-15663 
164. Peck SC, Chekan JR, Ulrich EC, Nair SK, van der Donk WA (2015) J Am Chem Soc 137:3217-3220

165. Metcalf WW, Griffin BM, Cicchillo RM, Gao J, Janga SC, Cooke HA, Circello BT, Evans BS, Martens-Habbena W, Stahl DA, van der Donk WA (2012) Science 337:1104-1107

166. Huang H, Chang WC, Lin GM, Romo A, Pai PJ, Russell WK, Russell DH, Liu HW (2014) J Am Chem Soc 136:2944-2947

167. Wang C, Chang WC, Guo Y, Huang H, Peck SC, Pandelia ME, Lin GM, Liu HW, Krebs C, Bollinger JM (2013) Science 342:991-995

168. Chang WC, Mansoorabadi SO, Liu HW (2013) J Am Chem Soc 135:8153-8156

169. Yun D, Dey M, Higgins LJ, Yan F, Liu HW, Drennan CL (2011) J Am Chem Soc 133:11262-11269

170. Higgins LJ, Yan F, Liu PH, Liu HW, Drennan CL (2005) Nature 437:838-844

171. Rajakovich LJ, Norgaard H, Warui DM, Chang WC, Li N, Booker SJ, Krebs C, Bollinger JM, Pandelia ME (2015) J Am Chem Soc 137:11695-11709

172. Bollinger Jr JM, Chang WC, Matthews ML, Martinie RJ, Boal AK, Krebs C (2015) In: Hausinger RP, Schofield CJ (eds) 2-Oxoglutarate-dependent oxygenases. R Soc Chem, pp 95-122

173. Hartwig JF (2016) J Am Chem Soc 138:2-24

174. Labinger JA, Bercaw JE (2002) Nature 417:507-514

175. Crabtree RH (2004) J Organomet Chem 689:4083-4091

176. Colby DA, Bergman RG, Ellman JA (2010) Chem Rev 110:624-655

177. Lyons TW, Sanford MS (2010) Chem Rev 110:1147-1169

178. Studer A, Curran DP (2016) Angew Chem Int Ed 55:58-102

179. Renaud P, Sibi MP (2001) Radicals in organic synthesis. Wiley$\mathrm{VCH}$, Weinheim

180. Huang X, Groves JT (2016) ACS Catal 6:751-759

181. Rossberg M, Lendle W, Pfleiderer G, Tögel A, Dreher EL, Langer E, Rassaerts H, Kleinschmidt P, Strack H, Cook R, Beck U, Lipper KA, Torkelson TR, Löser E, Beutel KK, Mann T (2006) Ullmann's encyclopedia of industrial chemistry. Wiley$\mathrm{VCH}$, Weinheim

182. Prier CK, Rankic DA, MacMillan DWC (2013) Chem Rev 113:5322-5363

183. Xie J, Jin H, Xu P, Zhu C (2014) Tetrahedron Lett 55:36-48

184. Fortman GC, Boaz NC, Munz D, Konnick MM, Periana RA, Groves JT, Gunnoe TB (2014) J Am Chem Soc 136:8393-8401

185. Bolm C, Legros J, Le Paih J, Zani L (2004) Chem Rev 104:6217-6254

186. Hill CL, Smegal JA, Henly TJ (1983) J Org Chem 48:3277-3281

187. Hill CL, Schardt BC (1980) J Am Chem Soc 102:6374-6375

188. Kruper Jr WJ (1982) The isolation, characterization and reactivity of high valent oxometalloporphyrins of chromium and manganese, Parts 1 and 2, Ph.D. Thesis, The University of Michigan, Ann Arbor

189. Depoorter B, Ricci M, Bortolini O, Meunier B (1985) J Mol Catal 31:221-224

190. Kojima T, Leising RA, Yan SP, Que L (1993) J Am Chem Soc 115:11328-11335

191. Puri M, Biswas AN, Fan R, Guo Y, Que L (2016) J Am Chem Soc 138:2484-2487

192. Planas O, Clemancey M, Latour JC, Company A, Costas M (2014) Chem Commun 50:10887-10890

193. Comba P, Wunderlich S (2010) Chem Eur J 16:7293-7299
194. Liu W, Groves JT (2010) J Am Chem Soc 132:12847-12849

195. Liu W, Groves JT (2015) Acc Chem Res 48:1727-1735

196. Liu W, Huang XY, Cheng MJ, Nielsen RJ, Goddard WA, Groves JT (2012) Science 337:1322-1325

197. Rueda-Becerril M, Sazepin CC, Leung JCT, Okbinoglu T, Kennepohl P, Paquin JF, Sammis GM (2012) J Am Chem Soc 134:4026-4029

198. Pitts CR, Bloom S, Woltornist R, Auvenshine DJ, Ryzhkov LR, Siegler MA, Lectka T (2014) J Am Chem Soc 136:9780-9791

199. Xia J-B, Zhu C, Chen C (2013) J Am Chem Soc 135:17494-17500

200. Amaoka Y, Nagatomo M, Inoue M (2013) Org Lett $15: 2160-2163$

201. O'Hagan D (2008) Chem Soc Rev 37:308-319

202. Furuya T, Kamlet AS, Ritter T (2011) Nature 473:470-477

203. Hollingworth C, Gouverneur V (2012) Chem Commun 48:2929-2942

204. Huang X, Liu W, Ren H, Neelamegam R, Hooker JM, Groves JT (2014) J Am Chem Soc 136:6842-6845

205. Miller PW, Long NJ, Vilar R, Gee AD (2008) Angew Chem Int Ed 47:8998-9033

206. Brooks AF, Topczewski JJ, Ichiishi N, Sanford MS, Scott PJH (2014) Chem Sci 5:4545-4553

207. Preshlock S, Tredwell M, Gouverneur V (2016) Chem Rev 116:719-766

208. Brase S, Gil C, Knepper K, Zimmermann V (2005) Angew Chem Int Ed 44:5188-5240

209. Thirumurugan P, Matosiuk D, Jozwiak K (2013) Chem Rev 113:4905-4979

210. Kochi JK (1974) Acc Chem Res 7:351-360

211. Jenkins CL, Kochi JK (1971) J Org Chem 36:3095-3102

212. Huang XY, Bergsten TM, Groves JT (2015) J Am Chem Soc 137:5300-5303

213. Yan M, Lo JC, Edwards JT, Baran PS (2016) J Am Chem Soc 138:12692-12714

214. Levin MD, Kim S, Toste FD (2016) ACS Cent Sci 2:293-301

215. Hu Y, Shaw AP, Estes DP, Norton JR (2016) Chem Rev 116:8427-8462

216. Kochi JK (1967) Science 155:415-424

217. Zuo Z, Ahneman DT, Chu L, Terrett JA, Doyle AG, MacMillan DWC (2014) Science 345:437-440

218. Noble A, McCarver SJ, MacMillan DWC (2015) J Am Chem Soc 137:624-627

219. Tellis JC, Primer DN, Molander GA (2014) Science 345:433-436

220. Kainz QM, Matier CD, Bartoszewicz A, Zultanski SL, Peters JC, Fu GC (2016) Science 351:681-684

221. Corcoran EB, Pirnot MT, Lin S, Dreher SD, DiRocco DA, Davies IW, Buchwald SL, MacMillan DWC (2016) Science 353:279-283

222. Ye Y, Sanford MS (2012) J Am Chem Soc 134:9034-9037

223. Wang J, Qin T, Chen T-G, Wimmer L, Edwards JT, Cornella J, Vokits B, Shaw SA, Baran PS (2016) Angew Chem Int Ed 55:9676-9679

224. Huang X, Liu W, Hooker JM, Groves JT (2015) Angew Chem Int Ed 54:5241-5245

225. Sharma A, Hartwig JF (2015) Nature 517:600-604

226. Karimov RR, Sharma A, Hartwig JF (2016) ACS Cent Sci. doi:10.1021/acscentsci.6b00214 